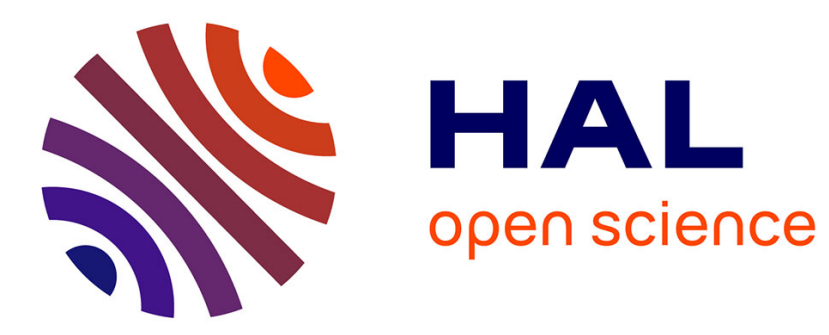

\title{
Ice production in Storfjorden (Svalbard) estimated from a model based on AMSR-E observations: Impact on water mass properties
}

Fernanda Jardon, Frédéric Vivier, Pascale Bouruet-Aubertot, Antonio Lourenço, Yannis Cuypers, S. Willmes

\section{To cite this version:}

Fernanda Jardon, Frédéric Vivier, Pascale Bouruet-Aubertot, Antonio Lourenço, Yannis Cuypers, et al.. Ice production in Storfjorden (Svalbard) estimated from a model based on AMSR-E observations: Impact on water mass properties. Journal of Geophysical Research. Oceans, 2014, 119, pp.377-393. 10.1002/2013JC009322 . hal-00993510

\section{HAL Id: hal-00993510 https://hal.science/hal-00993510}

Submitted on 4 Jan 2022

HAL is a multi-disciplinary open access archive for the deposit and dissemination of scientific research documents, whether they are published or not. The documents may come from teaching and research institutions in France or abroad, or from public or private research centers.
L'archive ouverte pluridisciplinaire HAL, est destinée au dépôt et à la diffusion de documents scientifiques de niveau recherche, publiés ou non, émanant des établissements d'enseignement et de recherche français ou étrangers, des laboratoires publics ou privés. 


\title{
Ice production in Storfjorden (Svalbard) estimated from a model based on AMSR-E observations: Impact on water mass properties
}

\author{
F. P. Jardon, ${ }^{1}$ F. Vivier, ${ }^{1}$ P. Bouruet-Aubertot,${ }^{1}$ A. Lourenço, ${ }^{1}$ Y. Cuypers,,${ }^{1}$ and S. Willmes ${ }^{2}$ \\ Received 2 August 2013; revised 15 November 2013; accepted 26 November 2013; published 21 January 2014.
}

[1] Storfjorden, which hosts a latent heat polynya, is a well known region of dense water formation. This Brine-enriched Shelf Water (BSW) displays substantial year to year variability in its properties, which is partly linked to interannual variations in ice production. Here we have developed a model based on high-resolution AMSR-E satellite sea-ice concentration data, available between 2002 and 2011, and atmospheric forcing to estimate the ice production in the polynya and associated salt release. The average modeled ice production for the epoch $2002-2011$ is $47 \mathrm{~km}^{3}$ per year, corresponding to a salt release of $1200 \times 10^{9} \mathrm{~kg}$. The two most anomalous winters were 2004-2005 (salt deficit of -367 $\times 10^{9} \mathrm{~kg}$ ) and 2007-2008 (salt excess of $398 \times 10^{9} \mathrm{~kg}$ ). Available observations of BSW properties are relatively scarce during this period and are here augmented with data collected in March 2007 from an ice-tethered mooring to the northwest of the fjord. BSW was found up to the surface, with maximum salinity and density of 35.27 and $28.4 \mathrm{~kg} \mathrm{~m}^{-3}$, respectively, at $55 \mathrm{~m}$. In addition, supercooled water was found down to $10 \mathrm{~m}$ under relatively mild atmospheric conditions. It is shown to have formed a week before, during an intense frazil ice formation episode, exceeding $2 \mathrm{~km}^{3}$ of frazil ice according to the model. Although observations remain too few to robustly assess the relation between ice production and BSW properties, there is suggestion of a direct impact for most anomalous years. The exceptional ice production in 2007-2008 is most likely the cause of the very saline BSW in 2008 and strong plume of dense water toward Fram Strait reported by other authors.

Anomalous ice production appears predominantly driven by the duration of the freezing season and anomalous opening of the polynya.

Citation: Jardon, F. P., F. Vivier, P. Bouruet-Aubertot, A. Lourenço, Y. Cuypers, and S. Willmes (2014), Ice production in Storfjorden (Svalbard) estimated from a model based on AMSR-E observations: Impact on water mass properties, J. Geophys. Res. Oceans, 119, 377-393, doi:10.1002/2013JC009322.

\section{Introduction}

[2] Coastal latent heat polynyas on Arctic continental shelves play a key role in the ventilation of the Arctic Ocean. These open water areas are maintained ice free in winter time by offshore winds and currents which transport the sea ice that is constantly being formed owing to intense heat loss to the atmosphere [Smith et al., 1990]. Brine is released during the freezing process, leading to the formation of dense Brine-enriched Shelf Water (BSW). The latter accumulates at the bottom of the shelf before it exits

\footnotetext{
${ }^{1}$ Laboratoire d'Océanographie et du Climat-Institut Pierre-Simon Laplace (LOCEAN-IPSL), Université Pierre et Marie Curie, Paris, France.

${ }^{2}$ Department of Environmental Meteorology, University of Trier, Trier, Germany.

Corresponding author: F. P. Jardon, Laboratoire d'Océanographie et du Climat-Institut Pierre-Simon Laplace, Université Pierre et Marie Curie, 4 Place Jussieu, Tour 45/55, 4ème étage, boîte 100, Paris FR-75005, France. (Fernanda.Jardon@locean-ipsl.upmc.fr)

(C)2013. American Geophysical Union. All Rights Reserved. 2169-9275/14/10.1002/2013JC009322
}

toward the deep ocean through slope convection. This ventilation process, which also occurs on the shelves of the Antarctic continent, is a major mechanism of formation of bottom and deep waters [e.g., Killworth, 1983]. According to Cavalieri and Martin [1994], Arctic polynyas produce all together between 0.7 and $1.2 \mathrm{~Sv}\left(1 \mathrm{~Sv}=10^{6} \mathrm{~m}^{3} \mathrm{~s}^{-1}\right)$ of BSW, a rate comparable with deep water formation in the Greenland Sea through open water convection [Smethie et al., 1986]. The formation of BSW is also crucial for maintaining the vertical stratification in the cold upper halocline of the Arctic [Aagaard et al., 1981].

[3] Storfjorden, in the Svalbard Archipelago (Figure 1), is one of these regions of dense water formation [Quadfasel et al., 1988]. It hosts a persistent polynya in the northeast part of the fjord, maintained open by northeasterly winds during winter [e.g., Haarpaintner et al., 2001]. Main water masses of the neighboring Norwegian Sea and Barents Sea, which are also predominantly found in Storfjorden, are North Atlantic Water (NAW) and Arctic Water (ArW) [e.g., Loeng, 1991]. Additional water masses are formed in the region such as Polar Front Water (PW), a product of NAW and ArW, Modified Atlantic Water (MAW) 


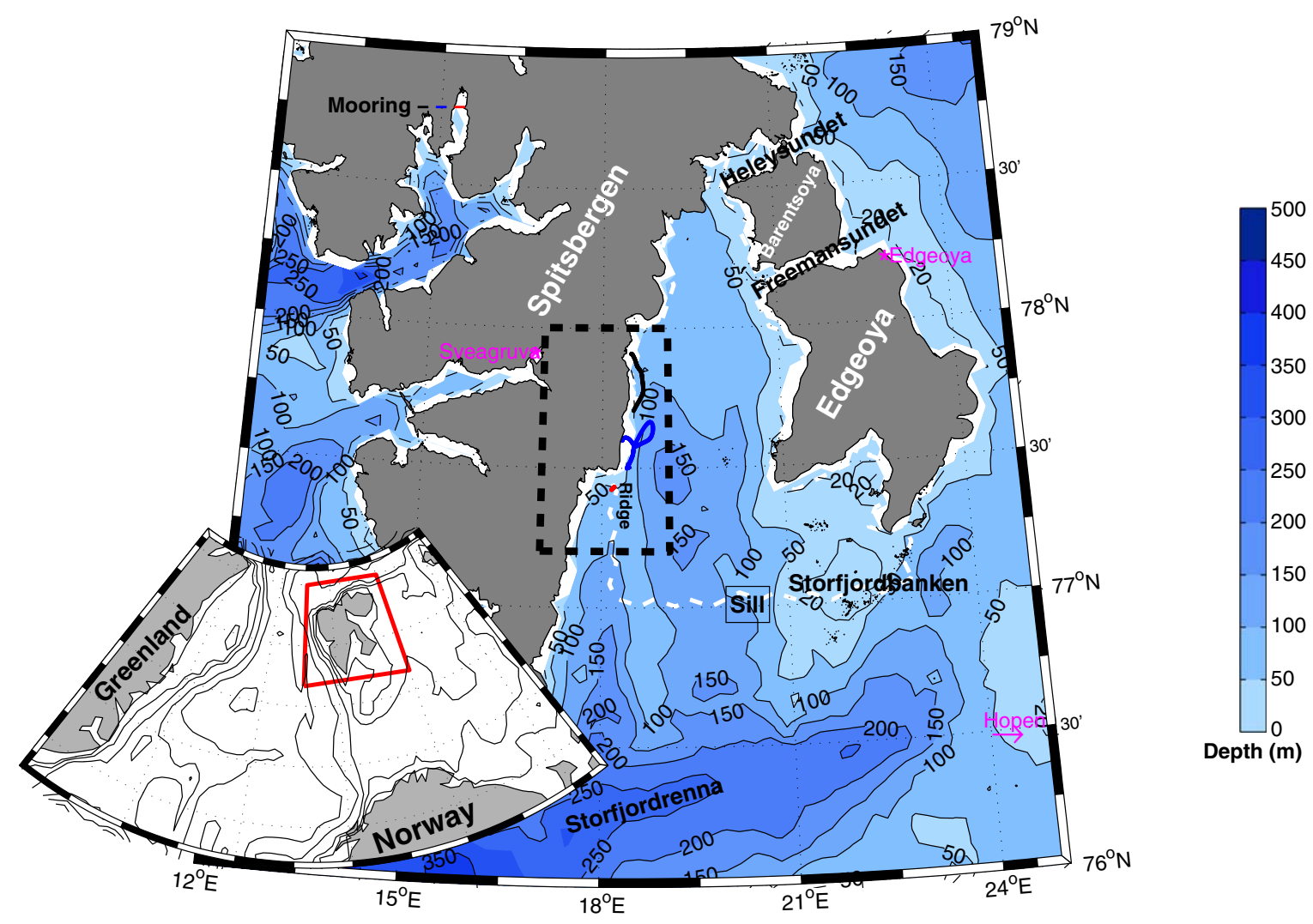

Figure 1. Storfjorden bathymetry from the $500 \mathrm{~m}$ resolution database of Skogseth et al. [2005a]. The line segments (black, blue, and red) denote the mean mooring trajectory over regions deeper than $50 \mathrm{~m}$. The white dashed line encloses the Storfjorden basin, over which ice production is computed. Meteorological stations Hopen, Edgeøya, and Sveagruva are indicated.

[Schauer, 1995], East Spitsbergen Water (ESW) carried by the eponymous current, and the dense BSW formed locally in the northeastern part of the fjord. Other water masses resulting from the melt of sea ice are found in summertime [Skogseth et al., 2005a]. We refer to Skogseth et al. [2005a] for a compilation of T-S characteristics of these water masses. BSW forms primarily from ArW in wintertime, with an annual rate of about 0.03-0.05 Sv [Schauer, 1995; Skogseth et al., 2005b]. Thus, BSW originating from the Storfjorden polynya accounts for about $5 \%$ of the dense water formed in the entire Arctic [Skogseth et al., 2004].

[4] Properties of the BSW show considerable year to year variability, with salinity ranging from 34.8 to a maximum of 35.8 and density between 28.01 and $28.87 \mathrm{~kg} \mathrm{~m}^{-3}$ [Skogseth et al., 2005b]. The volume and properties of BSW formed each year may be influenced by a variety of factors. These include the characteristics of the source water being transformed (e.g., properties of ArW at the beginning of the freezing season). Maus [2003] for instance reports that the maximum dense shelf water salinity formed during winter in the Svalbard Bank area is correlated with the surface salinity of the northwestern Barents Sea for the period 1952-2000. Skogseth et al. [2005a] further point out that MAW, PW, and ESW are all possible source water for specific years with very saline BSW. The location of the polynya with respect to the topography, that is whether brine rejection occurs above shallow or deeper regions, may also ultimately affect the properties of the BSW [Haarpaintner et al., 2001]. However, according to several authors, the volume of ice forming over the winter season is one of the most important parameters [Schauer, 1995; Skogseth et al., 2004]. There is thus great motivation to estimate interannual variations in the production of ice in this polynya, which is the main focus of this paper.

[5] Many works have been carried out to evaluate the ice production and dense shelf water formation over polynyas. Besides those based on full-blown atmosphere-ice-ocean or ice-ocean coupled models [e.g., Lynch et al., 1997; Goosse and Fichefet, 2001; Kusahara et al., 2010], alternate approaches have been developed to keep track of the polynya extent and estimate ice production: (i) those relying on relatively simple production-advection algorithms to predict the polynya opening [e.g., Pease, 1987; Haarpaintner et al., 2001; Skogseth et al., 2004] and (ii) those based on satellite observations to identify the open water fraction [Cavalieri and Martin, 1994; Toudal Pedersen and Coon, 2004; Tamura et al., 2008]. Among these studies, several authors considered the contribution from the growth of the preexisting pack/fast sea ice [Haarpaintner et al., 2001; Skogseth et al., 2004; Toudal Pedersen and Coon, 2004]. The others estimated the ice production owed to the sole polynya (open water and thin ice areas), based on the 
argument that the ocean-atmosphere net heat flux is several orders of magnitude higher in the polynya than through consolidated sea-ice [Smith et al., 1990]. In models where the continuous ice growth of the pack ice is included, advection is sometimes considered depending on the sophistication of the model [e.g., Toudal Pedersen and Coon, 2004].

[6] Monitoring polynya dynamics from remote sensing is the subject of active research. While SAR (Sythetic Aperture Radar) images provide the necessary spatial resolution, their limited temporal frequency often restricts their use to validate alternate approaches [e.g., Skogseth et al., 2004]. Instead many studies rely on passive microwave imagery, such as SSM/I (Special Sensor Microwave/ Imager), providing daily data since 1992, regardless of the cloud cover. Because the spatial resolution of SSM/I is relatively coarse $(25 \mathrm{~km} \times 25 \mathrm{~km})$ compared with the small scales of polynya regions, Markus and Burns [1995] developed a dedicated method, named PSSM (Polynya Signature Simulation Method) to better identify open water and thin ice areas, improving the data set spatial resolution to $\sim 5$ $\mathrm{km}$. Several works based on this approach have demonstrated the performance of the method, which increases the possibility to detect and characterize polynyas [Kern and Aliani, 2011; Willmes et al., 2011]. However, the AMSR-E (Advanced Microwave Scanning Radiometer-Earth Observing System) microwave product has been available since August 2002 with spatial resolution of $6.25 \mathrm{~km} \times$ $6.25 \mathrm{~km}$, thus providing sea-ice concentration at a substantially higher spatial resolution than SSM/I. Willmes et al. [2010] have adapted the PSSM to this new data set, with identical spatial resolution. Note that AMSR-E stopped operations in October 2011 due to instrument failure.

[7] Here, we have developed an ice production model fitting in the second category of approaches. We estimate the volume of ice formed in the polynya taking advantage of the high space/time resolution of AMSR-E sea-ice concentration satellite data. The model not only outputs new ice formation from open water area, but also cumulates ice production from consolidated ice based on a simple ice class algorithm. Simulations provide an estimate of the mass of salt rejected each year between 2003 and 2011, making it possible to examine the relationship with the observed BSW properties.

[8] Observations of BSW properties are relatively few, however. Here, we examine a series augmented with new observations collected in March 2007 from an ice-tethered mooring, equipped with autonomous temperature-salinity recorders. It was deployed in the northwestern part of Storfjorden (Figure 1) and drifted southward for a period of 10 days, allowing further documentation of the spatial distribution of water masses and their characteristics in late winter, which observation remains limited in this season according to the compilation of Skogseth et al. [2005a]. The mooring was positioned in the west part of the Storfjorden basin, while the polynya location is in the northeast part of the fjord, although it may open up on the western side during northwesterly and westerly winds. BSW was in particular observed at the mooring location, whether it was formed locally or brought about by the circulation. It is noteworthy that hydrographic observations were also collected on the opposite side of the fjord at the same period on board K/V Svalbard [Skogseth et al., 2013; McPhee et al., 2013].

[9] The remainder of this article is organized as follows. Section 2 begins with a description of the ice production model relying on AMRS-E observations. The model is used in section 3 to estimate the interannual variations of ice and brine production in Storfjorden for the period 2002-2011, thus extending previous model studies of Haarpaintner et al. [2001], Skogseth et al. [2004], and Skogseth et al. [2005b] who provide annual ice production up to 2002. We further examine the relative influence of different environmental factors in accounting for the year to year variability of ice production and conclude this section by contrasting the model simulation for the specific winter 2006-2007 with new hydrographic observations collected in Storfjorden in March 2007. Section 4 summarizes the main results of this study and ends on a concluding discussion on the potential link between interannual anomalies in ice production from 2002 to 2011 and the salinity of BSW from the few hydrographic observations available during this period.

\section{Data and Methods}

\subsection{Data}

\subsubsection{Sea-Ice Concentration}

[10] The daily sea-ice concentration from August 2002 to October 2011 is obtained from the AMSR-E instrument on board the Aqua satellite [Spreen et al., 2008]. The data, based on the ARTIST sea-ice (ASI) algorithm using 89 $\mathrm{GHz}$ brightness temperatures, is acquired from the Bremen University (http://www.iup.uni-bremen.de:8084/amsr/amsre.html). The Storfjorden basin has an area of $\sim 13,000 \mathrm{~km}^{2}$ (delimited by the white dashed line in Figure 1) [Haarpaintner et al., 2001; Skogseth et al., 2004], represented with this data by 321 pixels corresponding to a surface of $12,539 \mathrm{~km}^{2}$.

\subsubsection{Atmospheric Forcing}

[11] To compute the volume of ice formed annually in the polynya between 2002 and 2011, the daily net air-sea heat flux is needed by the model. The turbulent heat flux over water, comprising latent and sensible fluxes, was computed using the Coupled Ocean-Atmosphere Response Experiment (COARE) bulk algorithm version 3.0 [Fairall et al., 2003], assuming a surface temperature at the freezing point (simulations start each year when the presence of ice is detected from AMSR-E observations, see section 2.2). Daily averaged air temperature, relative humidity, pressure and wind speed, and direction, needed to compute the turbulent heat flux, were obtained from the European Center for Medium Range Weather Forecast (ECMWF) ERAinterim reanalysis [Simmons et al., 2006] at a $0.75^{\circ}$ spatial resolution.

[12] The net radiative flux was obtained by summing four-times daily upward and downward, shortwave and longwave radiative fluxes also from ERA-interim. A subset of the ERA-interim longwave fluxes, corresponding to the period of the field work to the northeast in Storfjorden (March-April 2007), was assessed by computing the net long wave heat flux from the Berliand formula [Budyko, 1974], using in situ meteorological data from the polar yacht Vagabond wintering about $10 \mathrm{~km}$ from the 
ice-tethered mooring deployment site. For this calculation the cloud cover information was, however, taken from the Hopen Island meteorological station. The correlation coefficient between the net longwave heat flux from ERAinterim and that computed from in situ observations is 0.54 , significant at $95 \%$, while the RMS difference is $25 \mathrm{~W} \mathrm{~m}^{-2}$.

[13] Finally, we note that the net heat flux derived here is in good agreement with that estimated by Skogseth et al. [2013] for the period 15-28 March 2007 from in situ meteorological measurements.

\subsubsection{Hydrographic Data Collected in 2007}

[14] The experimental set up included a main icetethered mooring spanning the whole water column $(60 \mathrm{~m})$ and one short $(15 \mathrm{~m})$ peripheral ice-tethered mooring $5 \mathrm{~km}$ further to the east, which is not discussed hereafter. The entire data set was used in Jardon et al. [2011] to investigate internal waves, but no water masses analysis was done in this work. The main mooring was deployed on 23 March 2007 at $17 \mathrm{~h}$ (day 82.7) on $40 \mathrm{~cm}$ thick fast ice covered by $20 \mathrm{~cm}$ of snow (ice freeboard was barely above 0 but positive), about $10 \mathrm{~km}$ offshore the site where the polar yacht Vagabond was wintering on the western side of Storfjorden under the auspices of the EU DAMOCLES project. It was equipped with 7 autonomous temperature sensors (RBR TR1050) and 5 Sea-Bird SBE37MP pumped Microcats, which record pressure, temperature, and conductivity with high accuracy $\left(0.25 \mathrm{dbar}, 0.002^{\circ} \mathrm{C}\right.$, and $\left.0.003 \mathrm{mS} \mathrm{cm}^{-1}\right)$. Here we will focus on data from the 5 Microcat instruments at a nominal depth of $1.8,10,20,30$, and $55 \mathrm{~m}$, respectively. Strong winds with warm air from southwest occurred a few hours after deployment, causing the fast ice to break up and setting the instruments adrift. Positions from Argos beacons indicate that the drift of the mooring started on 24 March at $11 \mathrm{~h}$ (day 83.4). The mooring was eventually recovered on 2 April 2007 (day 92) from R/V Lance sailing in the area. The mooring trajectory is displayed in Figure 1. It encountered two regions of shallow topography where the deepest instruments were dragged along the seafloor. The data record has thus been divided in three valid segments displayed in black, blue, and red from north to south in Figure 1. Data from the deepest Microcat are only available for segment 1 (black in Figure 1), before it touched the seafloor and got clogged with sediments.

\subsection{Model Description}

[15] Following Haarpaintner et al. [2001] and Skogseth et al. [2004], we distinguish ice production over open water, where frazil ice forms, from ice growth under consolidated ice. However, contrary to their approach, we do not use a model to track the polynya width and distinguish open water from ice covered areas, but rather rely on the daily AMSR-E sea-ice concentration. A mask is applied to AMSR-E data to restrict the domain of study to regions north of the $120 \mathrm{~m}$ deep sill where BSW accumulates (see white dashed line in Figure 1). The domain, which spans $12,539 \mathrm{~km}^{2}$ and includes in particular the shallow Storfjordbanken region, corresponds to the definition of the Storfjorden basin found in Skogseth et al. [2004].

[16] The model is run during the period of the year when the ice is present in the fjord, as determined from satellite observations. This period is hereinafter referred to as the ice season (IS). It starts with the freezing season (FS)
Table 1. Start and End Date as Well as Duration of the IS From 2002 to 2011 Identified From AMSR-E Data ${ }^{a}$

\begin{tabular}{lccc}
\hline Winter & From & To & Duration (in Days) \\
\hline $2002-2003$ & $23 / 10$ & $21 / 06(17 / 05)$ & $241(206)$ \\
$2003-2004$ & $21 / 10$ & $19 / 07(19 / 05)$ & $272(211)$ \\
$2004-2005$ & $17 / 11$ & $01 / 07(24 / 05)$ & $226(188)$ \\
$2005-2006$ & $29 / 10$ & $24 / 06(17 / 05)$ & $238(200)$ \\
$2006-2007$ & $05 / 11$ & $17 / 06(29 / 05)$ & $224(205)$ \\
$2007-2008$ & $07 / 10$ & $06 / 07(26 / 05)$ & $273(232)$ \\
$2008-2009$ & $27 / 10$ & $25 / 06(27 / 05)$ & $241(212)$ \\
$2009-2010$ & $2 / 11$ & $22 / 06(13 / 05)$ & $232(192)$ \\
$2010-2011$ & $11 / 11$ & $25 / 06(26 / 05)$ & $245(196)$ \\
\hline
\end{tabular}

${ }^{a}$ Shown in parentheses are the end and duration of the FS determined from the sign of the net heat flux (see text).

(negative net heat flux) and ends with the melting season (MS) in late spring. Satellite data reveal that there are a few coastal pixels where the sea-ice concentration remains nonzero also during summer. For the period August 2002October 2011, the maximum surface area corresponding to this summer land-fast (or glacier) ice is $1400 \mathrm{~km}^{2}$. The IS has therefore been defined as the period of the year when the total ice area in the domain exceeds a threshold of 1700 $\mathrm{km}^{2}$. This value was determined by testing the sensitivity of the length of the IS (LIS) to a threshold ranging from $1400 \mathrm{~km}^{2}$ to $2000 \mathrm{~km}^{2}$. The end dates appear stable for all thresholds, varying at most by 2 or 3 days. The start dates, however, are more sensitive to the threshold value, displaying a variability of up to 20 days, but are significantly more stable $\left( \pm 12\right.$ days) for surface areas greater than $1700 \mathrm{~km}^{2}$. The start and end date as well as the LIS are listed in Table 1. The LIS is maximum in 2008, starting earlier than the other years.

[17] Frazil ice will form mostly in the polynya itself but also in the leads appearing in the pack ice. Relatively large openings can be resolved by AMSR-E data (see for example the image on 4 April 2008 in Figure 11, Appendix A) and this additional open water area exposed to the atmosphere is accounted for by the corresponding sea-ice concentration (SIC). The open water area $A_{0}$, over which frazil can form, is therefore the sum over all pixels within the domain of $(1-S I C) \times \mathcal{A}_{p}$, where $\mathcal{A}_{p}$ is the pixel area $(39.06$ $\mathrm{km}^{2}$ ), while the complementary area is assumed to be covered by ice subjected to basal growth, which rate depends on the inverse of the ice thickness (see below). Because of the lack of ice thickness observation, we have developed a model to simulate the ice thickness distribution.

[18] We have assessed in Appendix A the ability to detect open water from AMSR-E SIC data, comparing in particular with estimates from the dedicated PSSM approach. Our definition of the polynya area as the cumulated open water fraction over the domain from satellite SIC contrasts somehow with the traditional definition of the polynya area as open water plus thin ice $(<\sim 10 \mathrm{~cm})$ areas, used in particular in the PSSM classification. Appendix A shows that both polynya areas are consistent. However, when comparing with results from other ice production models [e.g., Haarpaintner et al., 2001; Skogseth et al., 2004] one should bear in mind that ice produced from open water areas (frazil ice) in our approach is to be 
compared with ice produced not only from open water areas but also from the growth of thin ice areas, which together define the polynya in these models.

[19] The simplicity of the model lies in the fact that the domain is considered globally (no geographical coordinates). There is therefore no attempt to track the trajectory of parcels of ice in the fjord. It assumes instead a finite number of fixed discrete thickness classes $H_{i}$, finely sampled, ranging from zero (open water) to several meters (unrealistically large thickness classes in fact account for the export of ice, an issue discussed in section 3.2). The number of thickness classes exceeds 1000; their sampling depends on the thickness and is coarser for thicker class. Typically, classes are $2.5 \mathrm{~mm}$ thick between $0.5 \mathrm{~mm}$ and $10 \mathrm{~cm}, 5 \mathrm{~mm}$ thick up to $1 \mathrm{~m}$, and $1 \mathrm{~cm}$ or thicker beyond. The model variable, which evolves with time, is the area $A_{i}(t)$ associated with each thickness class $H_{i} . A_{i}(t)$ evolves on a daily time step (the sampling of AMSR-E data) as follows:

[20] Step 1: Freezing/Melting. We first examine the sign of the net heat flux to distinguish freezing from melting.

\subsubsection{Freezing}

[21] In the case of freezing, we use different expressions to compute the daily ice growth $d H$ for the zero thickness class (open water, with area $A_{0}(t)$ ) and for nonzero thickness classes (with associated areas $A_{i}(t), i>0$ ).

[22] Over open water area, following e.g., Skogseth et al. [2004], the equivalent thickness of frazil ice formed during one day $(d t)$ is a balance between the net heat flux $\left(Q_{n e t}\right)$ and the latent heat of fusion for sea ice $(L)$ :

$$
d H_{0}=-\frac{Q_{n e t}}{\rho_{f} L} d t,
$$

where $\rho_{f}$ is the density of frazil ice $\left(950 \mathrm{~kg} \mathrm{~m}^{-3}\right)$ and $L$ is equal to $234.14 \times 10^{3} \mathrm{~J} \mathrm{~kg}^{-1}$.

[23] A different expression is used for the continuous ice growth that takes place below congealed ice (thin, thick, land-fast ice), that is nonzero thickness classes in our terminology. Based on field studies [Anderson, 1961], it has been shown that the thickness of young sea ice is directly related to the cumulative number of freezing-degree days



$$
\zeta=\int_{0}^{t}\left(T_{f}-T_{a}\right) d t,
$$

where $T_{f}$ is the freezing point of the seawater and $T_{a}$ is the air temperature. As explained by Maykut [1986], the rate of growth becomes smaller as ice becomes thicker. Maykut [1986] formalized this empirical relation based on Stefan's law, deriving an expression for the continuous ice growth under ice-covered areas:

$$
d H=\frac{12.9}{2 H+16.8} d \zeta
$$

with both $d H$ and $H$ expressed in $\mathrm{cm}$. An extra term can be included in the denominator to account for the insulating effect of the snow layer. In this work, the snow layer is omitted as it is not accurately known. Haarpaintner et al.
[2001] showed that a snow layer thickness of $20 \mathrm{~cm}$ is reached by the end of the winter and variations in the snow increase rate in their model change the volume of the ice formed by less than 3\%. The accuracy of Maykut [1986]'s formulation has been tested against a state-of-the-art halothermodynamic sea-ice model [Vancoppenolle et al., 2010], verifying that both models reproduce reasonably similar results (not shown). Therefore, given the simplicity of Maykut [1986]'s model, we shall use expression (3), replacing $H$ by $H_{i}$ (with $i>0$ ) in our discrete classes model.

\subsubsection{Melting}

[24] Although the volume of ice melted is irrelevant for estimating the mass of salt released in the polynya (we ignore here the small contribution from brines that remain entrapped in sea ice which is released during melting), it is nevertheless important to account for the thinning of consolidated ice that occurs from sporadic melting episodes occurring before summertime so that the subsequent growth rate (and associated salt release) remains accurately estimated from equation (3). We opted for a very simple parameterization of melting, assuming that all the positive net heat flux into the ocean through open water areas is consumed to melt the ice from below (or laterally). Yet we assume throughout the simulation that the ocean remains at the freezing point so that equations (1) and (3) can still be used for subsequent ice formation. The main assumption behind such parameterization is that any increase in SST due to a positive net heat flux over open water areas is instantly lost (with respect to the daily time scale of the model) through ocean-ice heat flux, and therefore entirely used to melt the surrounding ice. Based on these premises, the positive net heat flux over area $A_{0}(t)$ induces a volume of ice melt through equation (1), which is evenly distributed over the area of nonzero thickness classes to yield a corresponding $d H$, with $d H<0$. This crude approach neglects in particular melting that occurs on the top of the ice. The sensitivity of the simulation to the parameterization of melting is discussed in section 3.2, where we increase the melting rate to account for neglected surface melt.

[25] Step 2: Reclassification. After the freezing/melting step, the new ice thicknesses must be redistributed within the discrete model's ice thickness classes. The area $A_{k}$ associated with $H_{k}$ is therefore modified assuming that the volume of ice is conserved (notation $A^{\star}$ is used to denote the forecast area at time $t+1$, prior to the assimilation step):

$$
\begin{aligned}
A_{k}^{\star}(t+1)= & A_{k}(t)+\frac{\left(H_{i}+d H_{i}\right) A_{i}(t)}{H_{i}}, \\
& \text { with } k \text { such that } H_{i}+d H_{i} \in H_{k} .
\end{aligned}
$$

[26] Step 3: Assimilation of observed sea-ice concentration. The total modeled sea-ice area $A_{c}(t+1)$ (with $\left.A_{c}(t+1)=\sum_{i>0} A_{i}^{\star}(t+1)\right)$ is then compared with the total sea ice area from AMSR-E, $A_{\text {sat }}(t+1)$. The ratio $\alpha=A_{c} / A_{\text {sat }}$ is used to rescale the area of each nonzero thickness class according to $A_{i}^{\dagger}(t+1)=A_{i}^{\star}(t+1) / \alpha$, which involves a concurrent thickness change $d H_{i}=(\alpha-1) H_{i}$ to preserve the ice volume. Similar to step 2, rescaled ice thicknesses are redistributed into the discrete classes of the model, adapting 
their area for volume conservation (equation (4)). The assimilation/reclassification steps are repeated until the deviation between the model and observed total ice cover area is smaller than $1 \%$, or alternatively until a maximum number of iterations is reached, yielding $A(t+1)$.

[27] However, when modeled total ice area is larger than satellite observations $(\alpha>1)$, which frequently occurs when frazil ice has formed as the open water fraction goes to zero, this rudimentary assimilation technique amounts to piling up the sea ice so that modeled and observed sea-ice areas match. As noted by Hendricks et al. [2011], Storfjorden, as an enclosed region, is prone to sea-ice deformation. This piling up of consolidated ice is a significant mechanism of thickening compared with thermodynamical growth. However, a thickness rescaling evenly distributed over all classes is not realistic as we expect thin ice to deform first. To reflect this, we instead proceed iteratively. The ice thinner than the equivalent thickness of the frazil ice formed during the time step, $d H_{0}$, which corresponds to a given class $p\left(d H_{0} \in H_{p}\right)$ is rescaled first to mimic the piling and accretion of thin ice that occurs on the lee side of the polynya (Skogseth et al. [2004] use for instance a collection thickness based on the wind speed). An appropriate scaling ratio for this subset of classes is thus defined, $\gamma=\left(\Sigma_{0<i \leq p} A_{i}^{\star}\right) /\left(A_{\text {sat }}-\Sigma_{i>p} A_{i}^{\star}\right)$, while thicker classes are not altered. We then increment $p$ in the assimilation/reclassification procedure so that increasingly thicker classes of ice are piled up until modeled and observed ice areas match.

[28] Steps 1-3 are repeated daily and the volume of frazil ice formed, $V_{\text {frazil }}$ as well as the volume of pack ice formed, $V_{\text {pack }}$ are cumulated. From these, the mass of salt rejected in the ocean due to ice formation is readily computed, following Skogseth et al. [2004]:

$$
M_{\text {salt }}=0.79 \times S_{o}\left(\rho_{f} V_{\text {frazil }}+\rho_{\text {ice }} V_{\text {pack }}\right),
$$

where $S_{o}$ is the initial salinity of the seawater, set to 34.15 for consistency with previous works, $\rho_{f}$ and $\rho_{\text {ice }}$ are the densities of the frazil and pack ice, respectively $\left(\rho_{\text {ice }}=\right.$ $917 \mathrm{~kg} \mathrm{~m}^{-3}$ ). The coefficient 0.79 is the fraction of surface water salinity that is released when ice forms (0.69) augmented by 0.1 to account for additional release when ice ages [Skogseth et al., 2004].

\subsubsection{Export/Import of Ice}

[29] An assumption of the model is that no ice is exported out or imported into Storfjorden. This is certainly arguable and although this does not impact the open water area in the model, as the latter is imposed by daily AMSRE images, this affects the ice thickness distribution. If the simulated thickness distribution is biased toward large values owing to excessive deformation, we may underestimate the volume of pack ice formed through thermodynamical growth as bottom ice formation depends on the inverse of ice thickness (equation (3)). In sensitivity experiments (see section 3.2), we therefore relaxed the hypothesis that there is no ice flux at the open boundary of the domain, by adding a fourth step to the algorithm. We allowed for an export of ice thicker than a critical thickness $H_{\text {cut }}$, simply setting the area of thickness classes larger than $H_{c u t}$ to zero. To preserve the ice area, strongly constrained by AMSR-E observations, the exported ice is replaced by ice with a thickness equal to the median ice thickness at the corresponding time step of the simulation. This is meant to mimic the import of ice into Storfjorden from the Barents Sea. Imposing a thickness equal to the median of the distribution is based on the assumption that this ice imported from adjacent seas has grown under forcings which are comparable to those encountered in Storfjorden.

\section{Results}

\subsection{Ice Production (Reference Simulation)}

[30] The model is run for each IS as provided in Table 1 with a daily time step. It is initialized each year with the observed sea-ice area from AMSR-E, which is assumed to belong to the $20 \mathrm{~cm}$ thickness class. The model is forced with the daily, basin-averaged, net heat flux and air temperature from ERA-interim. There is no import/export of ice in this reference simulation.

[31] Daily and accumulated ice production are shown in Figure 2 (bottom) for the specific winter 2006-2007 when we made measurements, jointly with the daily and accumulated net heat flux (top). The top plot shows that the variability of the forcing over the basin scale is relatively small (gray scale), suggesting that the 1D approach taken here is appropriate. Unsurprisingly, daily ice formation responds directly to the net heat flux, and the accumulated ice volume mirrors the accumulated net heat flux. This is consistent with the fact that frazil ice is the dominant contribution to the total volume of ice formed. The bottom plot shows that no ice forms after 29 May, which marks the end of the FS (the end and length of the FS obtained from the model are reported for each year in Table 1). Ice melts earlier in May (as indicated by the net volume of ice; not shown), but due to some sporadic episodes with negative net heat flux some ice keeps forming during this month, contributing to the total mass of salt rejected in the ocean. As seen in the figure, a total of $45.3 \mathrm{~km}^{3}$ of ice has formed at the end of the IS. Among this total, $88 \%$ represents the contribution from frazil ice (gray dashed line, Figure 2), while ice growth from the existing pack ice accounted for only $12 \%$ of the volume of ice formed (dashed-dotted line, Figure 2).

[32] The cumulated volume of frazil and pack ice, as well as the total volume formed from FS 2002-2003 to 2010-2011 are shown in Figure 3. The average total volume of ice formed during this period is $46.9 \mathrm{~km}^{3}$ per year resulting in an average salt release of $1196 \times 10^{9} \mathrm{~kg}$. Frazil ice stands for on average $85 \%$ of this total.

[33] Figure 3 features substantial interannual variability in the ice production, with a standard deviation of $7.9 \mathrm{~km}^{3}$. The most anomalous winters were 2004-2005 and 20072008 with a minimum and a maximum total ice production of $33 \mathrm{~km}^{3}$ and $63 \mathrm{~km}^{3}$, respectively. The variability of the total ice volume is dominated by the variability of the frazil ice volume: the maximum (minimum) contribution from pack ice to this total is of $24 \%(7 \%)$ in FS 2004-2005 (2007-2008).

\subsection{Sensitivity of the Model Runs}

[34] The formulation of the model is based on simple parameterizations which involve a choice for several parameters. It is legitimate to test the sensitivity of the 


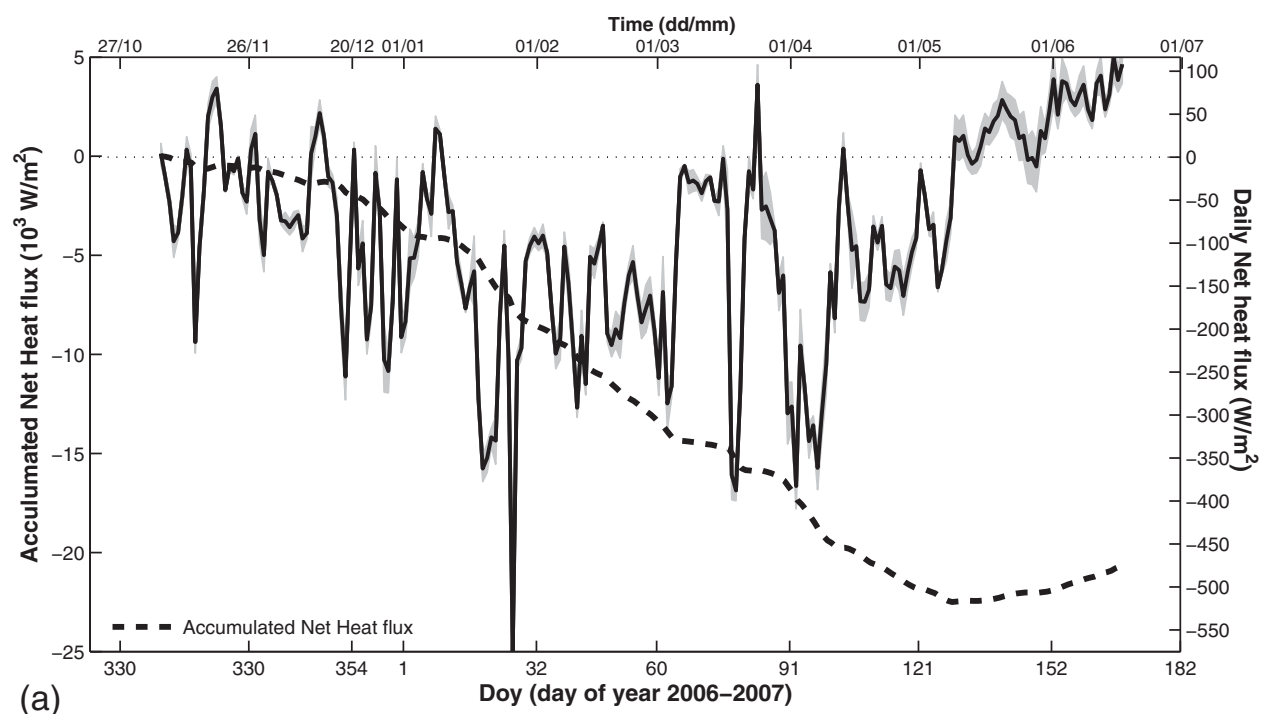

(a)

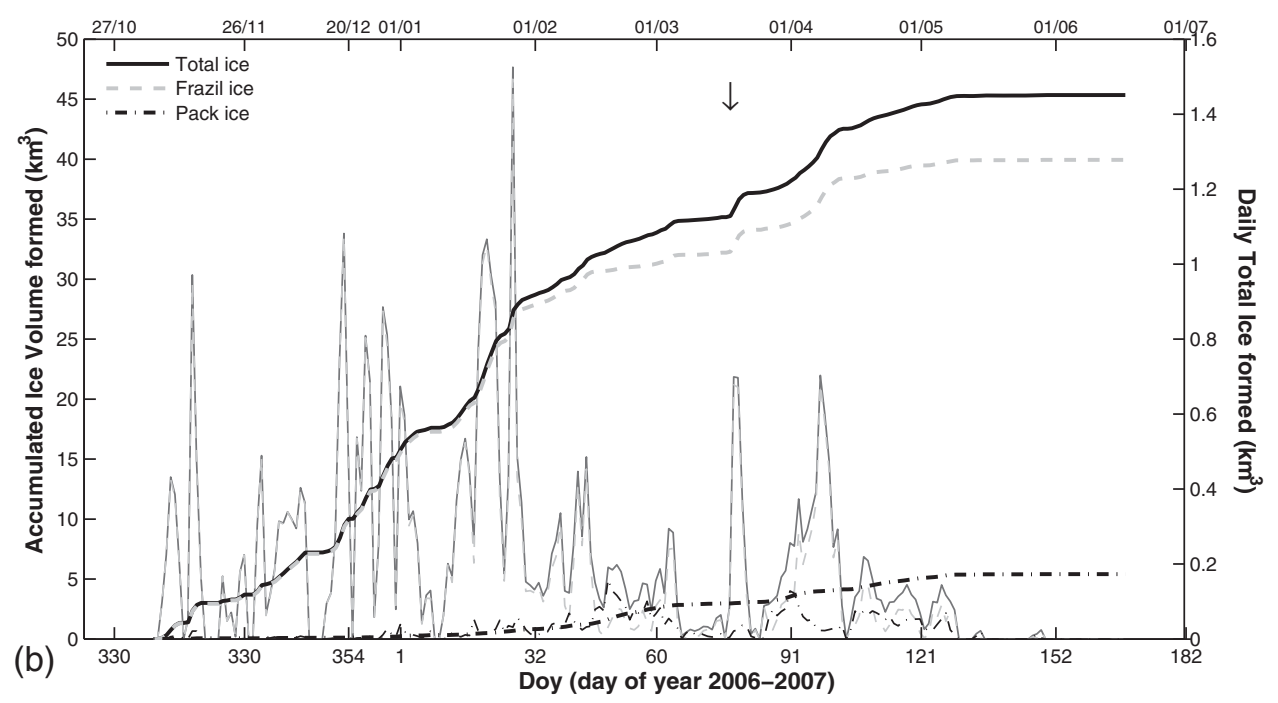

Figure 2. (top) Daily and accumulated net surface heat flux over open water ( $\mathrm{W} \mathrm{m}^{-2}$ ) during 20062007. The gray surface identifies the \pm 1 standard deviation of the surface mean over the entire Storjorden. (bottom) Daily (thin lines, right axis) and accumulated volume of ice formed (thick lines) for total (solid line), frazil (dashed line), and pack (dashed-dotted line) ice. Units are $\mathrm{km}^{3}$. The vertical arrow identifies the polynya opening shown in Figure 8.

results to these choices. We examine the impact of the prescription of the initial ice thickness, of the parameterization of melting, as well as of the consideration of import/export of ice into/out of Storfjorden.

\subsubsection{Initial Thickness}

[35] For the reference run, the model is initialized with an ice thickness of $20 \mathrm{~cm}$ over observed ice-covered areas. Additional runs were performed with an initial thickness of $10 \mathrm{~cm}$ and $30 \mathrm{~cm}$. These initial conditions yielded differences of less than $1 \%$ in the accumulated volume of ice formed at the end of the FS. This insensitivity to initial ice thickness is consistent with the fact that most of the ice production is owed to frazil ice during polynya events over open water area.

\subsubsection{Parameterization of Melting}

[36] As noted in section 2, our parameterization of melting neglects melting that occurs on the top of the pack ice owing to the positive net heat flux at the ice-atmosphere interface. This net heat flux is obviously more difficult to compute as this requires the knowledge of the ice (or snow) surface temperature. Instead, we parameterize this effect by assuming that the net heat flux at the surface of the ice is a fraction of the net heat flux over open water. This coefficient varies from 0 (no positive net heat flux applied over ice-covered areas) to 1 (the positive net heat flux used to compute melting over ice-covered areas is as large as the net heat flux over open water). This greatly increased melting at the end of the FS, but had little impact $(<1 \%)$ on the total volume of ice being formed over the season (not shown).

\subsubsection{Export/Import of Ice}

[37] The model gives a median ice thickness of $2.1 \mathrm{~m}$ over the FS in the reference simulation, which appears excessive and is due to the fact that ice piles up in the 


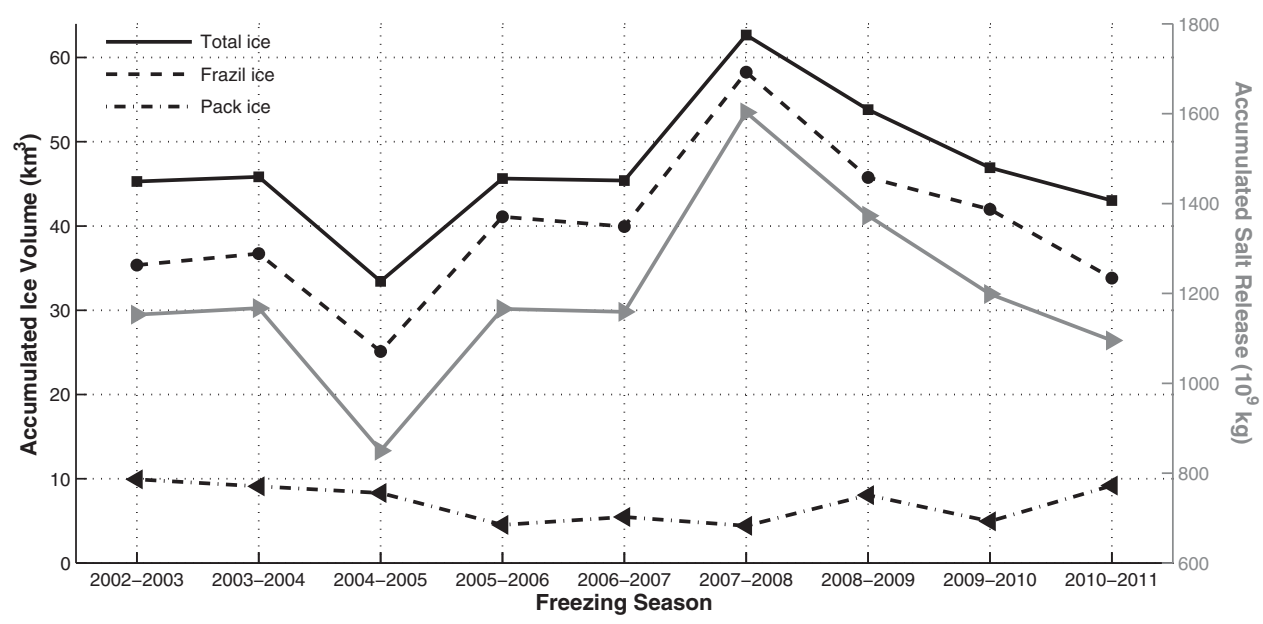

Figure 3. Volume of total (thick line), frazil (dashed line), and pack (dashed-dotted line) ice in $\mathrm{km}^{3}$ formed during each FS between 2002-2003 and 2010-2011. The associated total mass of salt released in $\mathrm{kg}$ for each FS is also shown (gray line, right axis).

model instead of being exported. There are few observations of ice thickness distribution in Storfjorden. Observations by Gerland and Hall [2006] are restricted to fast-ice areas. The only comprehensive observations of ice thickness distribution in Storfjorden to compare with were carried out by Hendricks et al. [2011] from three electromagnetic induction surveys in March 2003, May 2006, and March 2007. The sea ice locally formed in the polynya had a mean thickness of $\sim 0.5 \mathrm{~m}$, while it was $1.2 \mathrm{~m}$ for fast ice. The three "snapshot" surveys reveal large interannual variability, with in particular the intermittent presence of thicker imported ice from the Barents Sea with a mean thickness of $2 \mathrm{~m}$. An interesting finding from their analysis is that this external ice tends to thicken within the fjord through deformation, and may grow thicker than multiyear ice imported from the Central Arctic (as was found in 2003).
[38] Reproducing this complex year-to-year variability is out of reach of our model. It is nevertheless important to assess the sensitivity of the local ice production estimates to the ice thickness distribution. We have therefore relaxed the hypothesis that there is no ice flux at the open boundary of the domain, and allowed for an export of ice thicker than a critical thickness $H_{\text {cut }}$ (see section 2). In a simulation with $H_{\text {cut }}=120 \mathrm{~cm}$, the median thickness at the end of the FS reduces to $55 \mathrm{~cm}$, while the average total ice production is $55.4 \mathrm{~km}^{3}$, a $16 \%$ increase compared with the reference run, owed to an additional $8.5 \mathrm{~km}^{3}$ of pack ice (frazil ice formation naturally remains unaffected). It is interesting to note that this ad hoc parameterization of export is relatively insensitive to the cut-off thickness above which ice is exported. Using a cut-off thickness of $100 \mathrm{~cm}$, yields a median thickness of $52.5 \mathrm{~cm}$ over the FS and a mean ice production of $56.7 \mathrm{~km}^{3}$. For a cut-off thickness of $200 \mathrm{~cm}$,

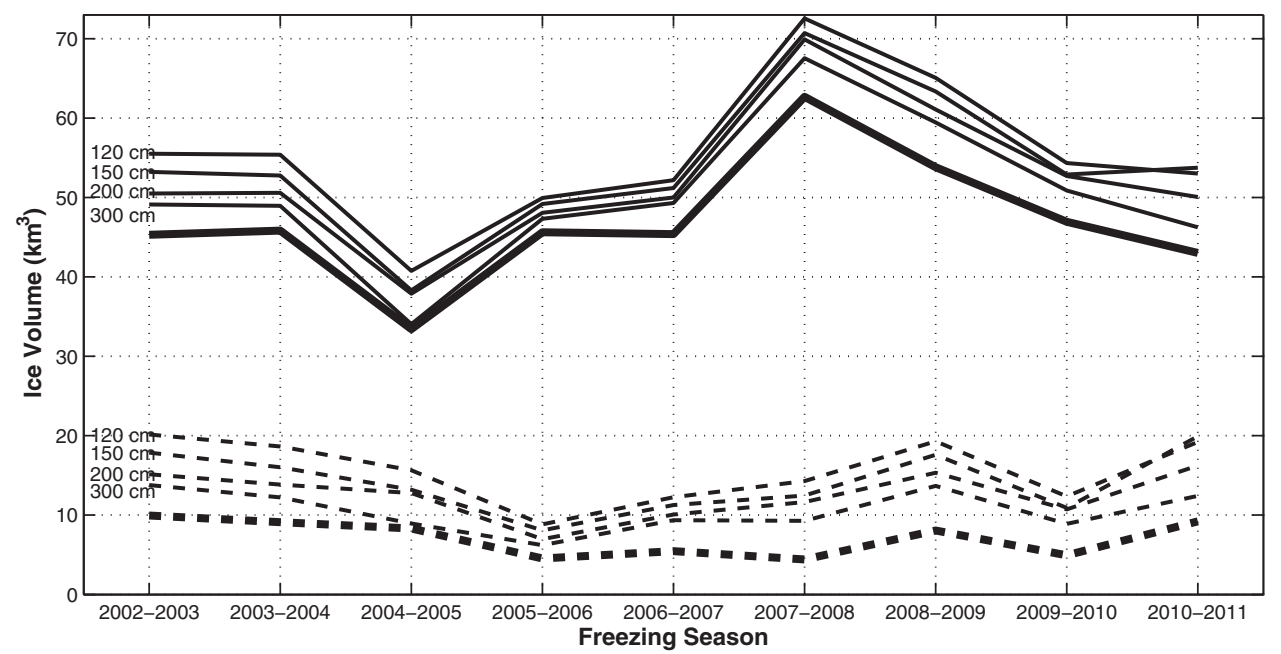

Figure 4. Sensitivity of the modeled total ice production (solid lines) and of modeled pack ice production (dashed lines) to the cut-off thickness for ice export (see text). Bold lines are for the reference run (with no parameterization of ice import/export), while thin lines are for runs with a cut-off thickness of $120 \mathrm{~cm}, 150 \mathrm{~cm}, 200 \mathrm{~cm}$, and $300 \mathrm{~cm}$. 


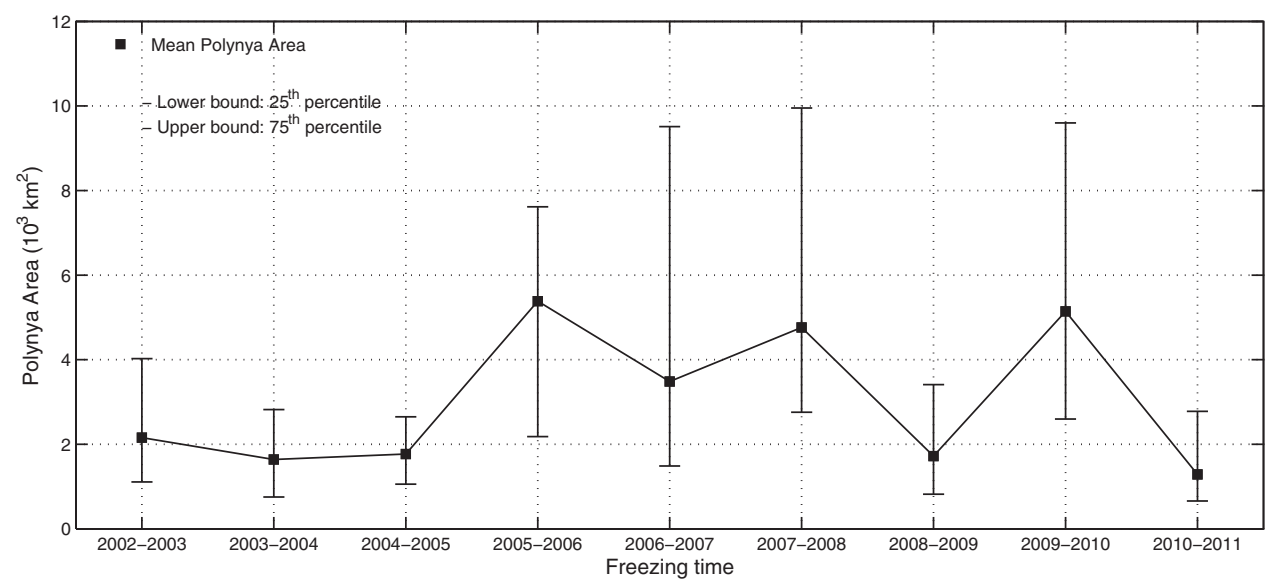

Figure 5. Mean 25th and 75th percentiles of the estimated open water area estimated for each ice season (IS) between 2002-2003 and 2010-2011 based on daily observed sea-ice concentration from AMSR-E.

the mean ice production is $52.3 \mathrm{~km}^{3}$. These results suggest that we may underestimate the annual average of the total ice production by as much as $9.5 \mathrm{~km}^{3}(\sim 20 \%)$ in the reference run due to an underestimation of the volume of pack ice formed.

[39] However, in all the sensitivity runs, the relative interannual variations remain nearly unchanged (Figure 4). This is not only due to the preeminence of the mechanism of frazil ice formation compared with pack ice formation, but also to the fact that interannual variations in the volume of pack ice formed remain overall consistent throughout the different sensitivity experiments. The effect of smaller cut-off thicknesses is mostly an overall increase of the pack ice production.

[40] In conclusion to these analyses, although the annual average of the total ice production may be underestimated by neglecting export, we are confident in the robustness of the featured anomalies, which we analyze hereafter.

\subsection{Factors Driving the Interannual Variability of Ice Production}

[41] Among these factors, we specifically examine the intensity of the net heat flux during the FS, the FSL (Table 1 ) and the mean opening of the polynya.

[42] The open water area, denoted $A_{0}$ in the model, is an important parameter characterizing the polynya. It is directly estimated from AMSR-E sea-ice concentration observations. Figure 5 displays the mean as well as the 25 th and 75 th percentiles of the open water area distribution for each IS from 2002 to 2011. This interquartile range provides an index of the polynya activity: the larger the range, the more variable the polynya.

[43] Annual mean values of the open water area (Figure 5) range between 2.1 and $6.1 \times 10^{3} \mathrm{~km}^{2}$, the maximum 75 th percentile occurs in 2008 and reaches $9.9 \times 10^{3} \mathrm{~km}^{2}$. These average values correspond to an open water fraction of $22.7 \%, 18.6 \%, 16.4 \%, 40.3 \%, 39.4 \%, 48.4 \%, 22.5 \%$,

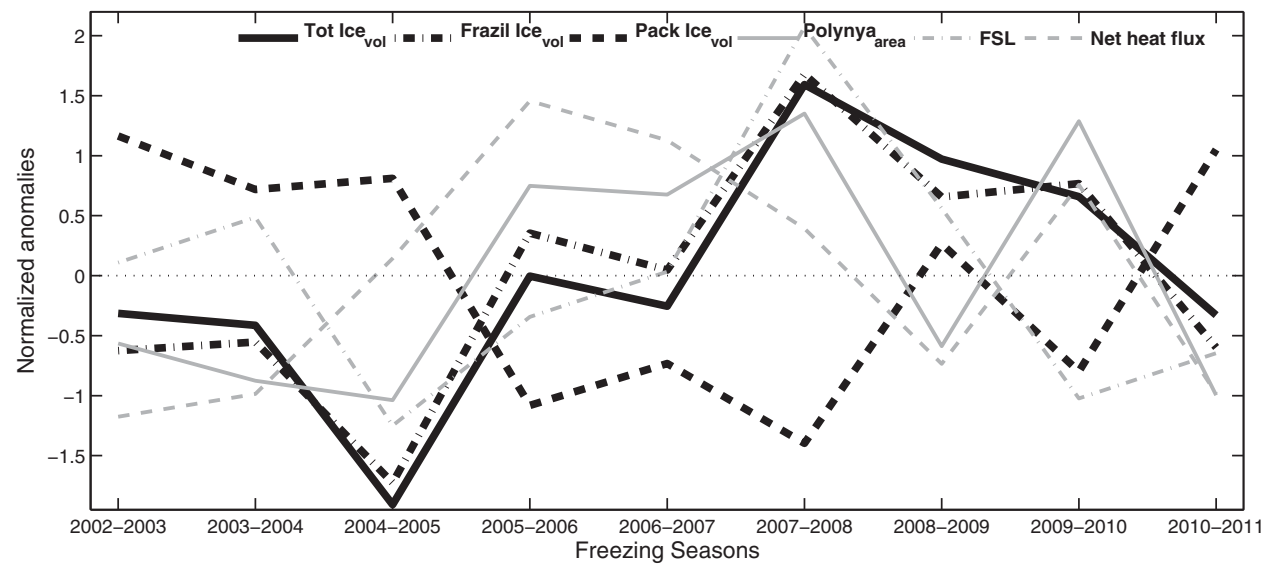

Figure 6. Anomalies of modeled total, pack and frazil ice production jointly with anomalies of estimated open water area from AMSR-E sea-ice concentration, net heat flux from ERA Interim reanalysis, and FSL (see Table 1). 
Table 2. Correlation Coefficient Between the Normalized Anomalies of the Annually Averaged Modeled Total, Frazil and Pack Ice Volumes, and the Open Water Area, the FSL (Freezing Season Length) and the Net Heat Flux ${ }^{\mathrm{a}}$

\begin{tabular}{llcc}
\hline & Total Ice & Frazil Ice & Pack Ice \\
\hline Open water area & $0.63(0.65)$ & $\mathbf{0 . 8}(0.65)$ & $\mathbf{- 0 . 9 4}(-0.64)$ \\
FSL & $\mathbf{0 . 7 1}(0.68)$ & $\mathbf{0 . 6 4}(0.62)$ & $-0.35(-0.66)$ \\
Net heat flux & $0.11(0.7)$ & $0.37(0.7)$ & $\mathbf{- 0 . 8 4}(-0.68)$ \\
\hline
\end{tabular}

${ }^{\text {a }}$ The $95 \%$ significance level is indicated in parentheses.

$47.5 \%$, and $17 \%$ for the respective years. These values, which average to $30.3 \%$, are slightly larger but overall consistent with previous estimates of the polynya area in Storfjorden. Indeed, based on SAR images and a polynya model Skogseth et al. [2005b] found a polynya area fraction (open water and thin ice) of $\sim 23 \%$ with the highest value in 2002 of $33.8 \%$.

[44] Figure 6 displays the normalized anomalies for the total, frazil and pack ice, together with the open water area, the net heat flux, and the FSL (see Table 1). The net heat flux and polynya area (open water area) have been averaged each year over the FS. Normalized anomalies of all variables are computed by removal of the 9 year mean and division of the residual by the standard deviation. The correlation coefficient among the different variables are shown in Table 2 together with the $95 \%$ confidence level.

[45] Unsurprisingly, anomalies in the total volume of ice follow anomalies in frazil ice formation (Figure 6). The net heat flux anomaly plotted in the figure must be understood as follows: a positive anomaly corresponds to less net heat loss to the atmosphere than the average (that is a warmer season). Anomalies in the pack ice production are significantly anticorrelated with the anomalous net heat flux (Table 2), meaning that a colder winter will drive larger pack/fast ice production. More surprisingly, frazil ice production anomalies show no significant correlation with the net heat flux, suggesting that other factors are more relevant. Indeed frazil ice production is instead significantly correlated (0.8) with anomalies in open water area, as a larger area of open water exposed to a cold atmosphere will produce a larger volume of frazil ice. However, the correlation is weaker (0.63) and actually not statistically significant when it comes to the total ice production, although frazil ice contributes with the majority. In fact, it is the correlation with the FSL that is largest and most significant (0.7). The large excess in ice production in winter 20072008 corresponds in particular to a much longer IS than average. Table 1 indicates that the FS started early October for this specific year, almost 1 month ahead of time. The fact that the open water fraction was larger than average during this winter also contributed to the exceptional ice production.

[46] We also examined correlations between ice production and the product of net heat flux anomalies and open water anomalies, as the coincidence of this two factors is likely to favor ice production, but they did not show statistically significant correlations. For such an analysis, however, consideration of the annual anomalies of the product of the two factors on a daily basis may be more relevant than the product of annual anomalies. We have also performed correlations based on air temperature anomalies instead of net heat flux and we have obtained similar results.

\subsection{Comparison With Hydrographic Data Collected in 2007}

[47] Although the Storfjorden polynya has been relatively well studied, available hydrographic observations of BSW for the period of simulation are relatively few. Here, we briefly analyze new hydrographic data collected in March 2007 and contrast them with the simulated ice production for the FS 2006-2007.

\subsubsection{Water Masses}

[48] A $\theta$-S analysis has been performed to identify water masses encountered by the drifting mooring at the different depths of Microcat instruments (Figure 7). Water masses are all close to the freezing point. We identify two water masses based on a salinity criterion: BSW with salinity larger than 34.8 in the north (Segments 1 and 2), and fresher ArW south of $78.5^{\circ} \mathrm{N}$, once the mooring line has passed the N-S ridge along $18.5^{\circ} \mathrm{E}$ (Figure 1). BSW is present throughout the water column north of $78.5^{\circ} \mathrm{N}$ (black and blue dots in Figures $7 \mathrm{a}-7 \mathrm{e}$ ). At the very beginning of the series, high salinity values, in excess of 35.5 are recorded for a few hours at the topmost instrument (Figure $7 \mathrm{a}$. These signals, which are not further discussed here, are possibly related to brine rejection from the warming sea ice due to gravity drainage [Jardon et al., 2013]. ArW, with $S<34.8$, is found in the upper $30 \mathrm{~m}$ as of 1 April 2007 (red dots in Figures $7 \mathrm{a}-7 \mathrm{~d}$ ). Prior to entering the ArW region to the west of the ridge, it is noteworthy that salinity gradually diminishes from 35.2 to 34.8 as the mooring drifts southward, suggesting mixing of BSW with ArW from the south. During the end of segment 2, one can observe that instruments above $20 \mathrm{~m}$ intercept ArW (Figures 7a and 7b, blue dots), while the deepest instruments are still located in the denser BSW layer. Consistently with these observations, Skogseth et al. [2013] report a gradual intrusion of fresher water entering Storfjorden from the south from their data collected at the same period on the opposite side of the fjord, which they attribute to the southerly winds.

[49] The densest BSW is sampled during segment 1 at depths greater than $30 \mathrm{~m}$ with values reaching $28.4 \mathrm{~kg} \mathrm{~m}^{-3}$ (salinity of 35.27). The BSW formed in 2007 is therefore saltier than the average maximal salinity of 35.19 for the period 1981-2002 (see Table 3 in Skogseth et al. [2005a]). Most recent published observations of BSW in Storfjorden go back to April 2006 [Skogseth et al., 2008] and March 2007 [Skogseth et al., 2013]. The former authors found the densest polynya water in the east side of Storfjorden with a density of $28.33 \mathrm{~kg} \mathrm{~m}^{-3}$ and salinity of 35.25 . In March 2007, Skogseth et al. [2013] report a salinity (density) as large as $\sim 35.5\left(28.6 \mathrm{~kg} \mathrm{~m}^{-3}\right)$ confined to the northeast region for very recently formed BSW that has not mixed yet with ambient water. In the deep part of Storfjorden, however, the densest BSW has a salinity ranging between 35.1 and 35.2 [Skogseth et al., 2013, Figure 7] consistent with the salinity of 35.27 from our observations. Completing the time series of salinity maximum [Skogseth et al., 2005a] with recent observations (April 2006 and March 2007), the updated average of salinity maximum is 

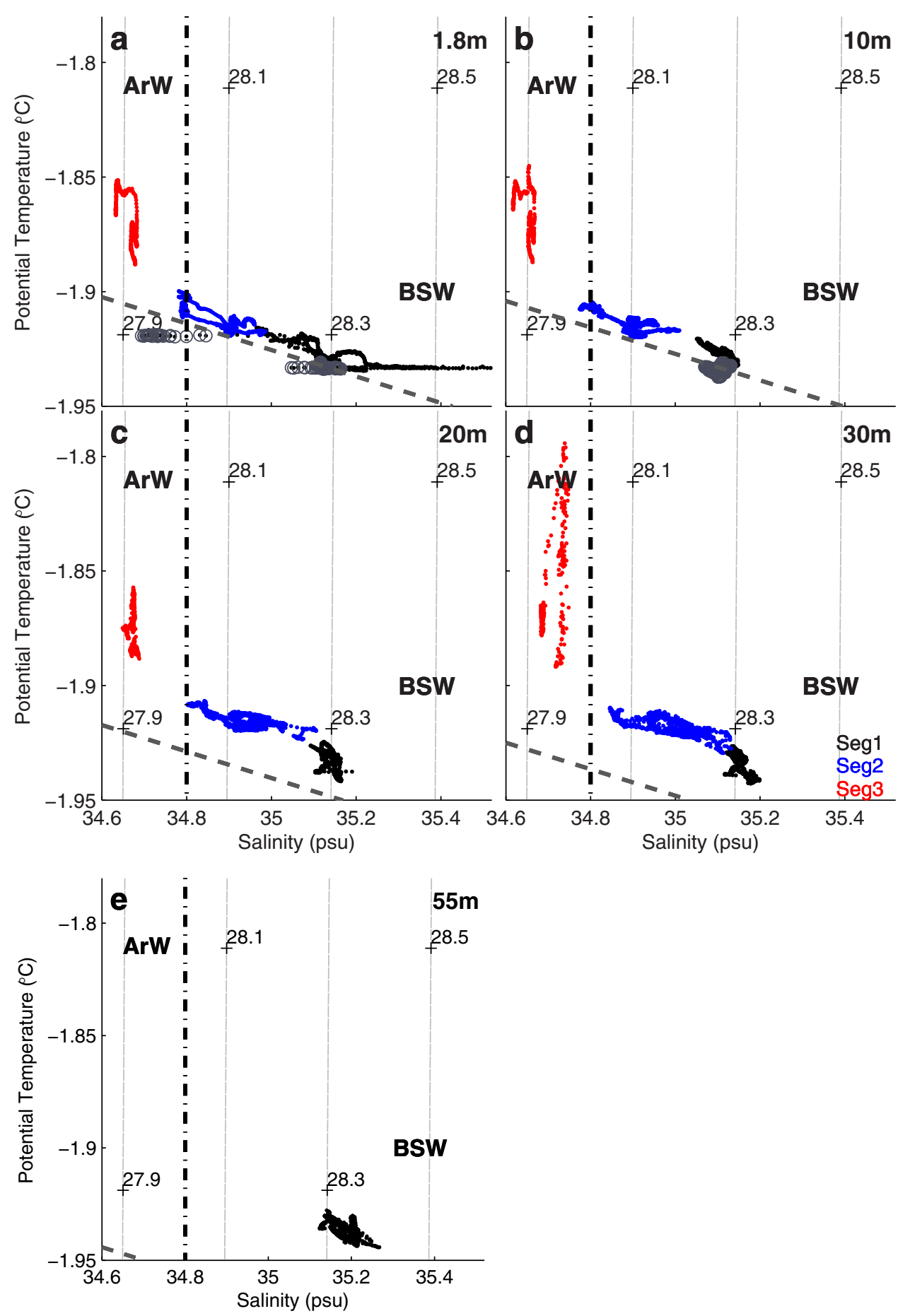

Figure 7. $\theta$-S diagrams at the successive depths of the 5 Microcats on the main mooring. Colors distinguish observations from each of the three valid data segments along the mooring drift (black, blue, and red from north to south, see Figure 1). The $\sigma_{\theta}$ contours (light gray dashed lines) are drawn every 0.2 $\mathrm{kg} \mathrm{m}^{-3}$. The water mass classification from Loeng [1991] and Skogseth et al. [2005a] is indicated. The dashed line denotes the freezing line. Points circled in gray are below the in situ freezing temperature.

$35.20 \pm 0.24$ over the period 1981-2007, while the averaged maximum potential density is $28.34 \pm 0.20 \mathrm{~kg} \mathrm{~m}^{-3}$.

[50] Consistent with the observation that the BSW salinity in March 2007 was only 0.07 larger than the longterm average, the simulated ice production for the FS 20062007 (Figure 2, bottom) amounts to a total of $45.3 \mathrm{~km}^{3}$, close to the average annual production over 9 years (46.9 $\mathrm{km}^{3}$ ), with therefore no significant anomaly in salt rejection (Figure 3).

\subsubsection{Supercooled Water and Frazil Ice Formation}

[51] Figures $7 \mathrm{a}$ and $7 \mathrm{~b}$ indicate that instruments down to $10 \mathrm{~m}$ detect the presence of in situ supercooled water 

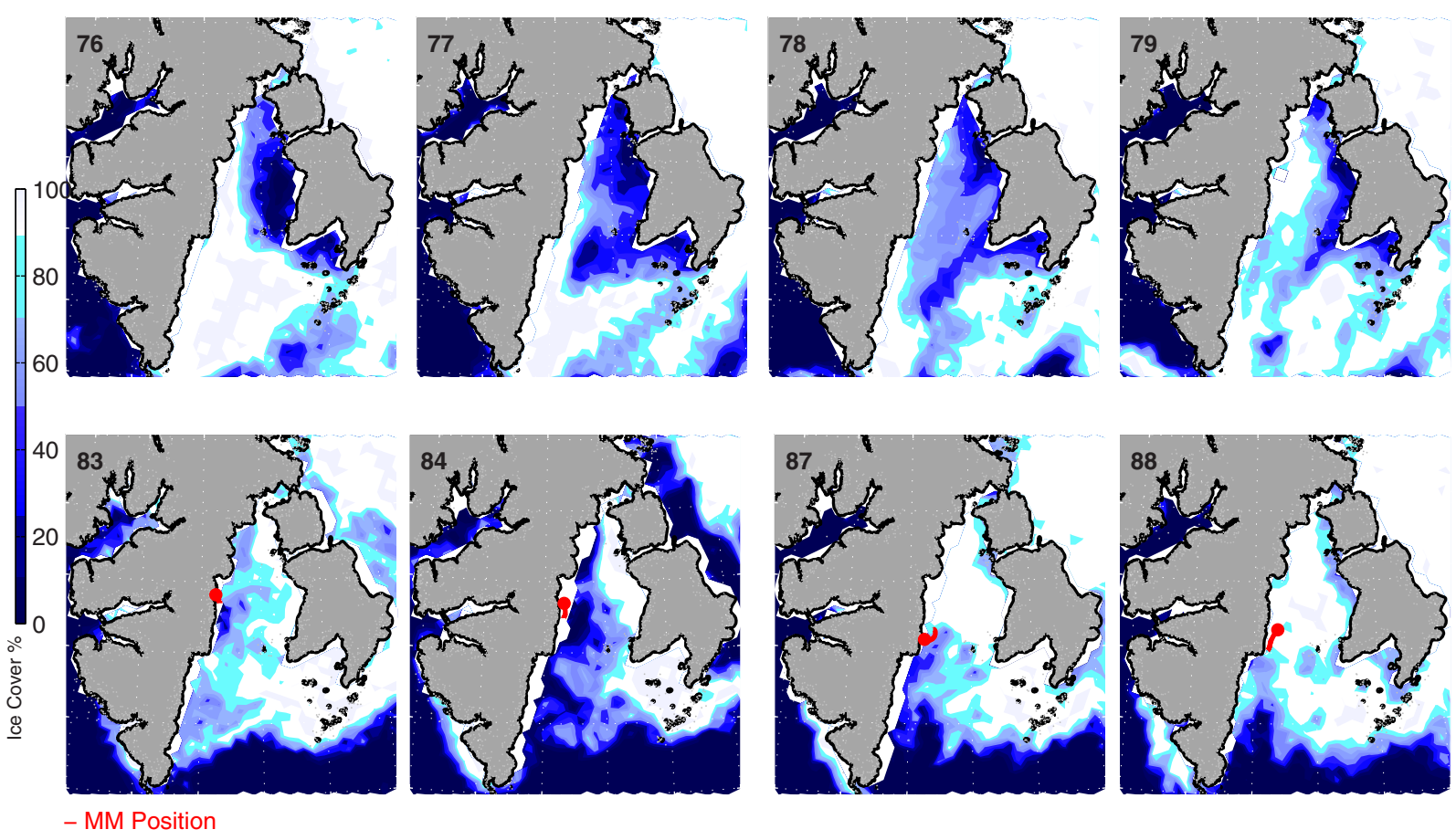

Figure 8. Daily sea-ice concentration maps at a $6.25 \mathrm{~km} \times 6.25 \mathrm{~km}$ resolution from AMSR-E (ASI algorithm) over Storfjorden for days 76 to 79 (17-20 March 2007; top); and 83, 84, 87, and 88 (24-29 March 2007; bottom). Daily main mooring trajectory (MM position) is superimposed in red as of day 83.

[Coachman, 1966; Lewis and Perkins, 1983], denoted by gray circles. Such points are identified based on the criterion $T<T_{f}-2 \times 10^{-3 \circ} \mathrm{C}$, that is the in situ temperature is below the freezing point $\mathrm{T}_{f}$ minus the sensor accuracy. Supercooling is observed only for the first $16 \mathrm{~h}$ of the record, under the ice, and stops when the ice breaks on day 83.5 , exposing the water to the anomalously warm atmosphere in this period. It is not the first time that supercooled water is detected in Storfjorden. Skogseth et al. [2009] measured water $0.037^{\circ} \mathrm{C}$ colder than the freezing point at a depth of $5 \mathrm{~m}$ in April 2006, compared $0.007^{\circ} \mathrm{C}$ here. A surprising aspect of our observations, however, is that supercooling is detected while the net heat flux into the ocean is positive (Figure 2, top). To better understand the presence of subsurface supercooled water, it is useful to examine the history of forcing and ice coverage prior to these observations.

[52] Figure 2 (top) shows that, prior to the mooring deployment, atmospheric conditions were indeed completely different with large net heat loss from the ocean, exceeding $350 \mathrm{~W} \mathrm{~m}^{-2}$ over open water. Six days before the experiment started (day 76), strong northeasterly winds (not shown) led to the opening of a very large polynya, progressing from the northeast to encompass most of the fjord. This situation is clearly observed in the sequence of daily images of sea-ice concentration (Figure 8, top). These open ocean conditions, with varying areas, are maintained during 4 days, until day 80 . The ice-free ocean lost large amounts of heat, reaching up to $390 \mathrm{~W} \mathrm{~m}^{-2}$ on day 77 , which are conditions prone to intense frazil ice formation. It is most likely that at this time, prior to ice consolidation, supercooled water formed in the upper $10 \mathrm{~m}$. This very active polynya episode, culminating on day 77-78, has also been recently analyzed by Skogseth et al. [2013]. They display MODIS and SAR satellite images of this sequence, which are consistent with AMSR-E images in Figure 8 but further clearly showing frazil ice streaks. They estimated a maximum net heat flux slightly exceeding $400 \mathrm{~W} \mathrm{~m}^{-2}$, consistent with our estimate of $390 \mathrm{~W} \mathrm{~m}^{-2}$. The sequence of images in Figure 8 (top) shows that the polynya closes progressively as ice continues forming. Subsequently, on day 83 , immediately after the mooring was deployed, the change of wind direction, bringing warm air masses over Storfjorden, induced a reversal of the sign of the net heat flux, warming the sea ice, and closing the polynya on the northeastern side and opening on the western side. This warm episode associated with southwesterly winds remained until day 85 .

[53] It is interesting to examine how this polynya event impacted ice production from the model perspective. A large amount of heat was released to the atmosphere from the open water in the polynya and a considerable volume of frazil ice was formed, as shown by the vertical arrow in Figure 2. The step in the graph of the cumulated ice volume indeed shows that $\sim 2 \mathrm{~km}^{3}$ of frazil was formed over 3.15 days (from 18 to 21 March).

\section{Summary and Concluding Discussion}

[54] To examine the potential link between BSW salinity, $S_{\mathrm{BSW}}$, and ice production, we have developed a model for ice formation in the Storfjorden polynya, in the spirit of 
previous approaches [Haarpaintner et al., 2001; Skogseth et al., 2004], but taking advantage of the unprecedented spatial resolution of the AMSR-E sensor $(6.25 \mathrm{~km} \times 6.25$ $\mathrm{km})$, which has provided daily sea-ice concentration between 2002 and 2011. Unlike previous works, there is no attempt to track polynya openings. After a growth or melting step, the total area of ice from AMSR-E data is crudely assimilated on a daily basis, yielding to a redistribution of thickness classes to preserve the total volume of ice.

[55] The average ice volume estimated from the model for the $2002-2011$ epoch is $46.9 \pm 7.9 \mathrm{~km}^{3}$ per year, corresponding to a release of salt of $1196 \times 10^{9} \pm 200 \times 10^{9}$ $\mathrm{kg}$. This production, mostly contributed by frazil ice $(85 \%)$, is larger but overall consistent with the $40 \mathrm{~km}^{3}$ reported by Skogseth et al. [2004] for the period 1998-2002, and comparable to the production of other major coastal polynyas of the Arctic (e.g., $55 \mathrm{~km}^{3}$ for the Laptev sea polynya) [Willmes et al., 2011]. A possible cause for the larger values found here may be that the latter model assumes an opening of the polynya in the northeastern part of the fjord only during favorable (northeasterly) wind directions, while in our approach based on AMSR-E data, sea ice opening is not restricted to a specific region of the fjord. In particular, sea ice opening in the western part of the fjord during wind directions (southwesterly) that close the polynya in the northeast is also taken into account. Differences may also stem from our definition of the polynya area from AMSR-E SIC, discussed in Appendix A.

[56] Sensitivity tests revealed that although the average annual ice production may be somewhat sensitive to the parameterization (up to $15-20 \%$ higher if we account for the export of ice), interannual variations remain robust over all the sensitivity runs, featuring two particularly anomalous winters : 2005 (negative) and 2008 (positive). Accordingly, the mass of salt rejected in 2005 was anomalously low, with a deficit of $-346 \times 10^{9} \mathrm{~kg}$, while 2008 corresponds to anomalously high ice production and large salt rejection with an excess of $406 \times 10^{9} \mathrm{~kg}$ (Figure 3 ).

[57] Causes for this significant interannual variability were investigated by examining the correlation with various likely influential parameters. Although our 9 year long series of ice production remains somewhat short for robust statistics, analyses indicate that the duration of the freezing season (FS) appears as the dominant factor driving anomalies in ice production, with correlations higher than with anomalous net heat fluxes or open water area (which are nonetheless significant). In the winter 2007-2008, the FS started in particular almost 1 month in advance, yielding an exceptional ice production, although an anomalously large polynya area also contributed to this maximum.

[58] Observations of BSW properties remain relatively few, and we reported here on additional data collected in March 2007 from an ice-tethered mooring deployed in the west part of the fjord. The densest BSW was found at the deepest sensor at $55 \mathrm{~m}$ with a density of and a salinity (density) of $35.27\left(28.4 \mathrm{~kg} \mathrm{~m}^{-3}\right)$, slightly saltier than the average of 35.20 of historical observations of maximum $S_{\mathrm{BSW}}$ between 1981 and 2007. Furthermore, supercooled water $\left(0.007 \pm 0.002^{\circ} \mathrm{C}\right.$ below the in situ freezing point) was recorded under ice down to $10 \mathrm{~m}$ during the first $16 \mathrm{~h}$ of measurements, before the ice broke up. An intriguing aspect of this observation is that it occurred under warm atmos- pheric conditions, with air temperature above zero and a positive net air-sea heat flux. An analysis of the sea-ice concentration and the net heat flux prior to the mooring deployment indicated that supercooled water was formed $\sim 6$ days before observation, during an episode of intense polynya activity and frazil ice formation. The model simulation shows that a frazil ice volume exceeding $2 \mathrm{~km}^{3}$ formed over 3 days yielding a salt rejection of $\sim 50 \times 10^{9} \mathrm{~kg}$. These observations suggest that subsurface supercooled water can persist for several days after the freezing period provided it is insulated from the atmosphere by the ice cover.

[59] This active polynya episode has also been recently discussed by Skogseth et al. [2013], who collected observations on the opposite side of Storfjorden at the same period as ours. Newly formed BSW caused the formation of a salinity front at the entrance of Freemansundet, where they documented transient supercooling and the presence of frazil ice crystals under fast ice. They further suggest that supercooling might have originated in the differential mixing of salt and heat (double diffusion) through the salinity front separating two water masses near their freezing point [McPhee et al., 2013]. It is difficult to say whether such mechanism might be an alternative explanation for our observations on the west side of the fjord, especially as we did not detect such salinity front.

[60] A question we meant to address with this model is to what extent interannual variability of the ice production in the polynya (and associated brine release) impact the properties of the BSW, which undergo interannual variations as large as unity in salinity [Schauer, 1995; Skogseth et al., 2004]. Although characteristics of the source water are reported as an influential factor for such variability, Skogseth et al. [2004] found good match between ice production and $S_{\mathrm{BSW}}$. The extremely dense BSW (28.87 kg $\mathrm{m}^{-3}$ ) measured in 2002 [Anderson et al., 2004; Fer et al., 2004], which led to an exceptional plume of dense water down to the Fram Strait area [Schauer et al., 2003] was in particular associated with a record high ice production in Storfjorden [Skogseth et al., 2005b]. However, this relationship broke with more recent hydrographic observations [Skogseth et al., 2008], suggesting that local preconditioning and additional larger scale factors are also influential.

[61] We reexamine here this question for a different epoch (2002-2011), based on a different ice production model. Anomalies in salt rejection of Figure 3 are reported in Figure 9 (gray line, right axis) together with the few observations of $S_{\mathrm{BSW}}$ available for this period: these include the April 2006 data from Skogseth et al. [2007] collected near the sill at $77^{\circ} \mathrm{N}$, data from this study in March 2007, as well as more recent observations made from R/V Håkon Mosby in September 2008 in the deepest part of Storfjorden, where a stronger than average $S_{\mathrm{BSW}}$ of 35.5 was measured (F. Nilsen, personal communication, 2012). The available database is of course too limited to discuss correlations between the series. We should also caveat that a single hydrographic snapshot may not be representative of the entire season if the salinity of BSW has strong intraseasonal variability, as is for instance the case for its volume transport at the sill [Geyer et al., 2010]. Nevertheless, there is suggestion of a relation between the mass of salt rejected (or equivalently anomalous volume of ice formed) over the season and the variations of $S_{\mathrm{BSW}}$. In 2006 and 


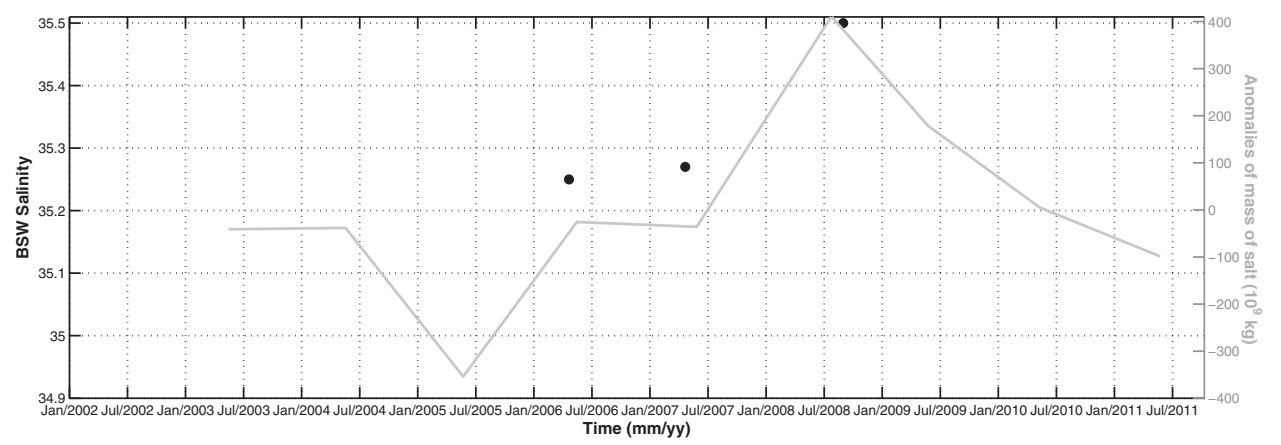

Figure 9. BSW salinity (black dots) and anomalies of the mass of salt rejected during the FS (gray line, right axis) estimated from the model. Salinity value in 2006 is from Skogseth et al. [2008], the value in 2007 is from this study, and the value in 2008 has been communicated by F. Nilsen. The salinity axis is centered about the 35.2 long term mean, while anomalies in the mass of salt are relative to the 20022011 mean.

$2007, S_{\mathrm{BSW}}$ was slightly larger than the average from historical observations of 35.20 , while ice production was also close to average. Contrary, the FS 2007-2008 was strongly anomalous and the excess of salt rejection coincides with a BSW 0.3 saltier than average measured a few months later. If we relate the anomaly of salt rejected in $2008(406 \times$ $\left.10^{9} \mathrm{~kg}\right)$ to the annual average volume of BSW $\left(10^{12} \mathrm{~m}^{3}\right.$ according to Skogseth et al. [2005b]), this corresponds to a salinity increase of 0.40 , consistent with the 0.3 salinity anomaly measured by Nilsen et al. Considering that the $2008 S_{\mathrm{BSW}}$ was measured in late summer (September), 5 months after BSW generally reaches its maximum salinity (in April) [Skogseth et al., 2004, 2005b], the value of 35.5 should probably be considered as a lower bound for $S_{\mathrm{BSW}}$ in 2008 .

[62] Interestingly, Goszczko et al. [2008] analyzed repeated summertime CTD observations collected annually from 2001 to 2008 in the framework of the IOPAS Arctic experiment. These casts were performed downstream of the sill across the shelf, in Storfjordrenna and along the west coast of Spitsbergen. They noted outstanding plumes of dense water close to the bottom on the slope spreading up to $79^{\circ} \mathrm{N}$ both in 2002 and 2008 . These plumes were observed to cascade along Storfjordrenna, carrying substantially denser (saltier) water than other years. They measured a high value of $S_{\mathrm{BSW}}$ of $\sim 35.3$ in Storfjordrenna in 2008 , denser than that of 2002, suggesting that the water formed in 2008 in Storfjorden must have been anomalously saline compared to the previous 8 years.

[63] Continuous series of hydrographic observations are needed in the polynya and in the downflow regions for a better assessment of the factors driving the production of dense water. It is quite clear from this study, however, in line with previous works, that an exceptionally high ice production has a substantial impact on dense water properties and thus on their fate (plumes cascading in the deep basin). This work also illustrates the benefit that can be expected from the high resolution satellite database of seaice concentration from AMSR-E and its sequel AMSR2 (successfully launched on 18 May 2012) for the study of confined polynya regions, both in the Arctic and in the shelves of Antarctica.

\section{Appendix A: Assessment of the Storfjorden Polynya Area Determined From AMSR-E Sea-Ice Concentration Data}

[64] Monitoring the dynamics of coastal latent heat polynyas from remote sensing, which provides both a synoptic view and continuous time series, is a subject of ongoing research. Only SAR imagery is able to produce information with a very high spatial resolution (a few $10 \mathrm{~m}$ ). However, because of their coarse temporal resolution, SAR images need to be combined with a model able to track the polynya extent between SAR scenes [e.g., Haarpaintner et al., 2001; Skogseth et al., 2005b]. Alternatively, passive microwave sensors (such as SSM/I) have provided global coverage observations since 1992 even over cloud-covered skies. Nevertheless, the spatial resolution of this data set is too coarse $(25 \mathrm{~km} \times 25$ $\mathrm{km}$ for sea-ice concentration) with respect to typical polynya scales. This prompted the development of a dedicated method to estimate coastal polynyas extent: the PSSM (Polynya Signature Simulation Method) initially developed by Markus and Burns [1995] based on the classification of brightness temperatures. The PSSM allows to distinguish between thick ice, thin ice, and open water at an improved spatial resolution (approximately $5 \times 5 \mathrm{~km}$ ) which increases the possibility to detect and characterize polynyas with remarkable applications in Antarctica [e.g., Kern and Aliani, 2011] and in the Arctic [e.g., Martin et al., 2007]. Thin ice is defined as ice with thickness of up to $20 \mathrm{~cm}$ [Kern et al., 2007], although the transition from thin to thick ice might actually be closer to $10 \mathrm{~cm}$ (S. Kern, personal communication, 2011).

[65] The more recent AMSR-E, launched in 2002, has an enhanced spatial resolution $(6.25 \times 6.25 \mathrm{~km})$. The ice production model developed in this paper heavily relies on sea-ice concentration (SIC) from AMSR-E, based on the ARTIST sea-ice algorithm [Spreen et al., 2008]. The underlying hypothesis is that, given the high spatial resolution of AMSR-E, SIC data are robust enough to detect the polynya area with a reasonable accuracy. This hypothesis nevertheless needs to be assessed by comparison with alternate methods/data sets.

[66] Taking advantage of a similar antenna footprint, several studies have adapted the PSSM to the AMSR-E 


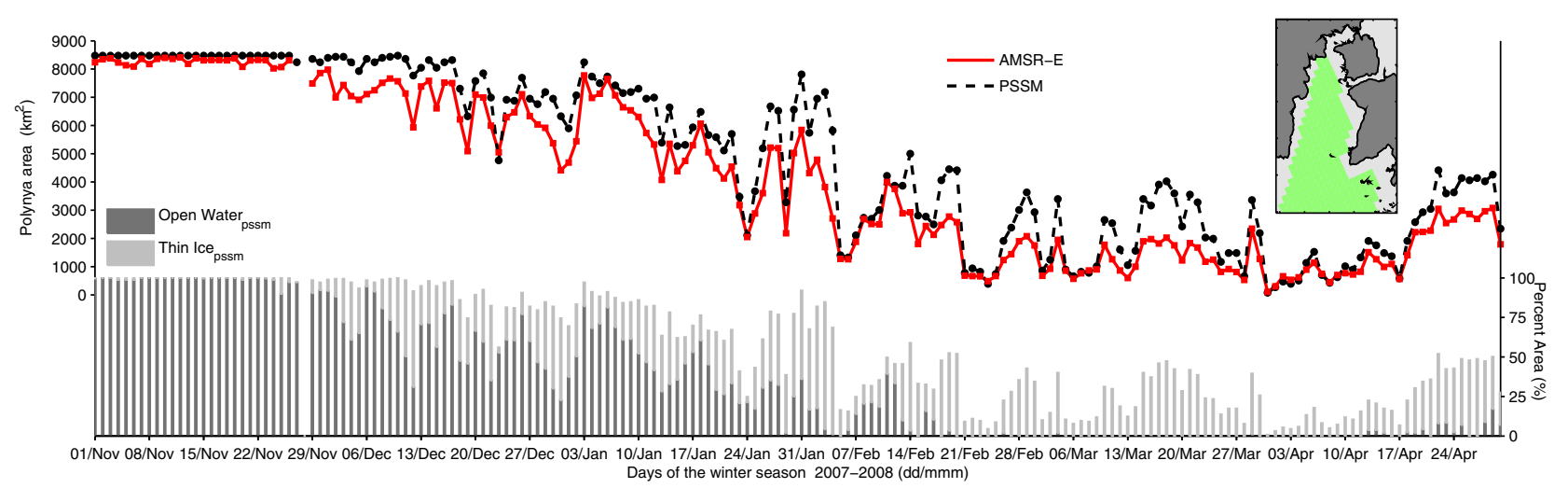

Figure 10. Polynya area in Storfjorden (green area in the inset) from the AMSR-E sea-ice concentration data set (red line) and from the Polynya Signature Simulation Method method (PSSM, black line). The bar graph identifies the daily area contribution of open water and thin ice to the polynya area based on the PSSM method.

data set to obtain the same ice classification as with SSM/I (open water, thin ice, and thick ice), with a spatial resolution of $6.25 \times 6.25 \mathrm{~km}$ [e.g., Willmes et al., 2010]. Studies by Willmes et al. [2010] and Willmes et al. [2011] have demonstrated that this adaptation outperforms the identification of the polynya areas compared with the PSSM applied to SSM/I data, but to the best of our knowledge no comparison between the PSSM method based on AMSR-E and the ARTIST SIC product from the same sensor has been done.

[67] Here we present a comparison between the polynya area (POLA) obtained from both AMSR-E PSSM and SIC for the 2007-2008 freezing season in the Storfjorden basin. On the one hand, POLA is identified as ice-free areas from AMSR-E SIC data following:

$$
\mathrm{POLA}_{\text {sic }}=\text { Area }_{\text {pixel }} \times\left(1-\mathrm{SIC}_{\mathrm{AMSR}-\mathrm{E}} / 100\right)
$$

[68] On the other hand, POLA $A_{\mathrm{pssm}}$ is derived from the PSSM method [Markus and Burns, 1995; Willmes et al., 2010]. Following Willmes et al. [2010], POLA $\mathrm{pssm}_{\text {refers to }}$ open water plus thin ice.

[69] Daily POLA are obtained in the Storfjorden region during one winter season, from 1 November 2007 until 30 April 2008 over 217 pixels with a $6.25 \times 6.25 \mathrm{~km}$ spatial resolution (Figure 10). The temporal evolution of daily POLA presents a remarkable correspondence between the two methods (Figure 10, upper axis) with a correlation coefficient of 0.93 . Largest differences occur during periods where the PSSM method does not identify open water areas, for example around 20 March featuring instead thin ice. Actually during the period between mid-February and mid-April, the PSSM method does not identify any pixel free of ice over the fjord. This is consistent with the findings of Kern et al. [2007] who show that open water from the PSSM classification corresponds to SIC of $\sim 30 \%$ or less and thin ice to a SIC of $\sim 60 \%$ or less. However, the absence of open water from the PSSM seems at odds with the literature which reports important polynya activity in late winter (e.g., March) [Skogseth et al., 2004]. This is also exemplified in the main body of the paper for March 2007 (see Figure 2). These differences may significantly impact ice formation (and hence brine release) as one expects a larger ice production in open water than from continuous growth under thin ice. This is quantified later in this appendix.

[70] To better illustrate similarities and discrepancies in the POLA anomalies from both methods, we display several true-color images (Figure 11) from MODIS radiometer on board the TERRA ${ }^{3}$ satellite with very high spatial resolution $(250 \mathrm{~m})$. We selected scenes where only thin ice is found from the PSSM method while SIC suggests ice-free regions. Among these examples, we discuss in particular two cases: (i) days with important open water areas completely or substantially ignored by the PSSM method and (ii) days with ice fractured with leads. The former case includes days of 14 March and 8 April. Despite the presence of some clouds, it is easy to observe areas of open water in the eastern part of Storfjorden, along the west coast of Edgeøya and Barentsøya. Regarding the second case (ii), images on 26 March and 4 April also present open water areas mostly to the eastern and central-southern, part of the fjord, where MODIS images suggest that the sea ice is fractured and leads are present. In none of these cases, the PSSM method features areas with open water, suggesting instead thin ice.

[71] This comparison would suggest that the PSSM method underestimates open water regions where highresolution MODIS images instead suggest leads or open water. In this respect, SIC data seem to more accurately picture the situation. We note, however, that there is a loss of resolution when applying the PSSM method to AMSR-E data compared with SIC POLA. The latter is based solely on $89 \mathrm{GHz}$ channels with a fine spatial resolution $(6 \mathrm{~km} \times$ $4 \mathrm{~km}$ ) while the former also includes the $37 \mathrm{GHz}$ channel that has a larger foot print $(14 \mathrm{~km} \times 8 \mathrm{~km})$. We also note that the PSSM method is very sensitive to the thresholds/ tie-point (in this case a threshold of 0.07 is used for the 89 $\mathrm{GHz}$ polarization ratio) used in the classification algorithm, and superior performances could probably be reached with additional tuning for this specific region.

[72] While MODIS images appear quite compelling, one needs to remain cautious, however, on their interpretation. 


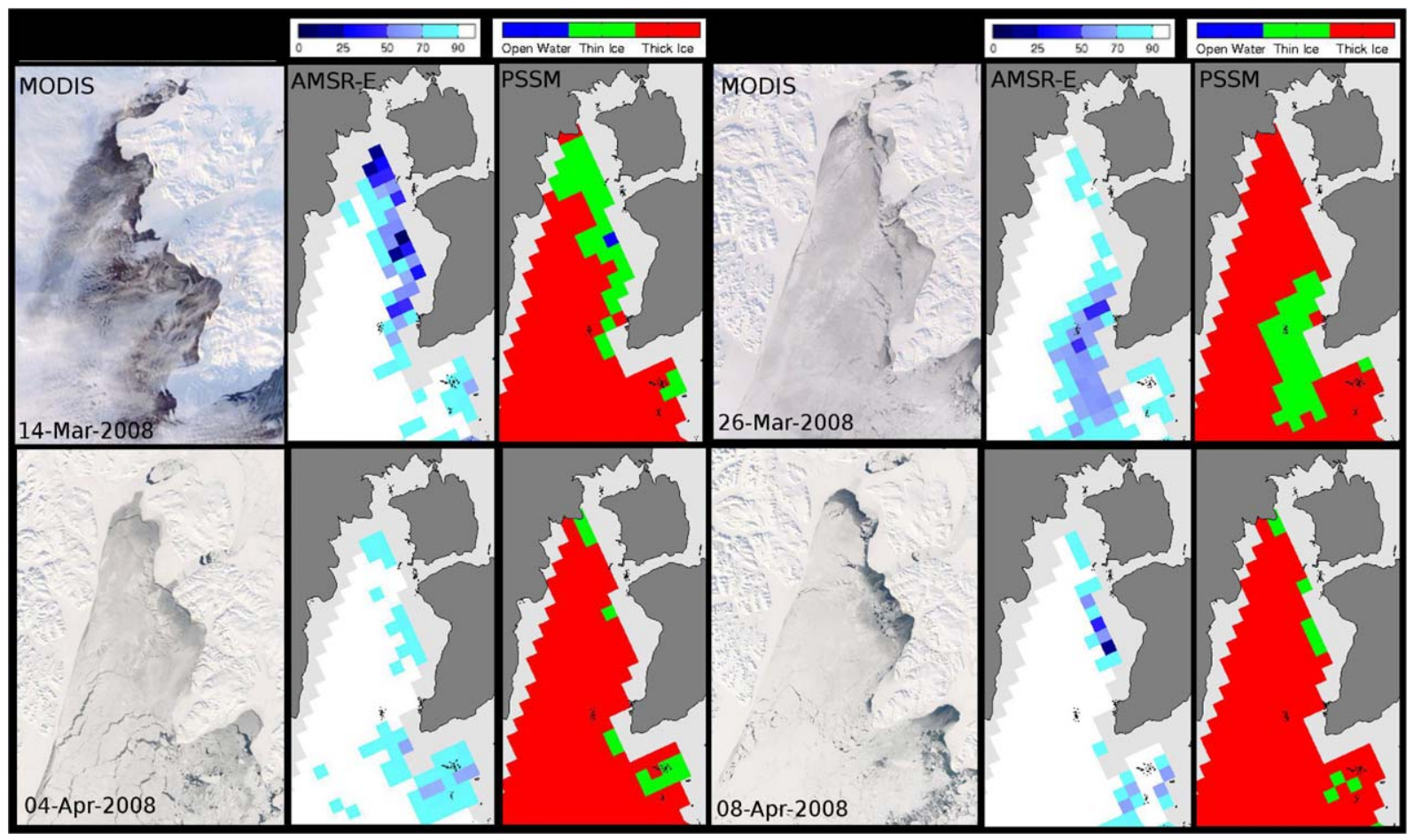

Figure 11. True-color Modis images jointly with AMSR-E ice concentration (\%) and open water, thin ice and thick ice classification from PSSM method for 14 March 2008, 26 March 2008, 4 April 2008, and 8 April 2008.

Indeed dark area may not always correspond to open water (dark nilas have for instance an albedo which is close to that of open water, S. Kern, personal communication, 2011) and a threshold would need to be applied on reflectance values to unambiguously distinguish open water from nilas or grease (new thin ice). Therefore to be complete on the impact of determining POLA from SIC rather than from PSSM, we estimated the discrepancies in terms of ice production from the two methods. We therefore additionally computed ice growth based on the PSSM classification applying instead expression (3) to compute ice growth below thin ice area, assuming a thickness of $10 \mathrm{~cm}$ (S. Kern, personal communication, 2011), and expression (1) for the PSSM open water. During the period depicted in Figure 10, we estimated $36.79 \mathrm{~km}^{3}$ of ice for POLA AMSR and $31.3 \mathrm{~km}^{3}$ of ice for POLA ${ }_{\text {PSSM }}$, a discrepancy on the order of $\sim 15 \%$. These results correspond to a particular winter. It would be interesting in future works to compare both methods for longer time series in the aim to test the sensitivity of different parameters.

[73] Acknowledgments. We thank the French National Research Agency, ANR (grant ANR-09-BLAN-0227-01) and Institut Polaire PaulEmile Victor, IPEV (programs 1058 and 1015) for their support. Field work was funded by IPEV, and benefited from logistics installed as part of the EU DAMOCLES integrated project. The participation of Hervé LeGoff (LOCEAN) was key to the success of mooring operations. We warmly thank E. Brossier and F. Pinczon du Sel from the Polar Yacht "Vagabond" for their help. We are indebted to the crew of R/V Lance for the recovery of the main mooring. The high-resolution bathymetry of Storfjorden was provided by R. Skogseth (UNIS), and the salinity of BSW in 2008 was kindly communicated by Frank Nilsen (UNIS). We are very grateful to S. Kern for instructive personal communications on the PSSM technique. AMSR-E ASI sea-ice concentration data were provided by the University of Bremen, MODIS images by LANCE/NASA. F.J. was supported by Program AlBan, the European Union Program of High Level Scholarships for Latin America, scholarship E07D403997AR, with extended support from CNES. Finally, we thank the valuable contribution from three anonymous reviewers that greatly helped to improve this manuscript.

\section{References}

Aagaard, K., L. K. Coachman, and E. C. Carmack (1981), On the halocline of the Arctic Ocean, Deep Sea Res., Part A, 28, 529-545.

Anderson, L. (1961), Growth rate of sea ice, J. Glaciol., 3, 1170-1172.

Anderson, L., E. Falck, E. P. Jones, S. Jutterstrom, and J. H. Swift (2004), Enhanced uptake of atmospheric $\mathrm{CO} 2$ during freezing of seawater: A field study in Storfjorden, Svalbard, J. Geophys. Res., 109, C06004, doi: 10.1029/2003JC002120.

Budyko, M. I. (1974), Climate and Life, 508 pp., Academic, New York

Cavalieri, D., and S. Martin (1994), The contributions of Alaskan, Siberian, and Canadian coastal polynyas to the cold halocline layer of the Arctic Ocean, J. Geophys. Res., 99, 18,343-18,362.

Coachman, L. K. (1966), Production of supercooled water during sea ice formation, in Proceedings of the Symposium on the Arctic Heat Budget and Atmospheric Circulation, 31 Jan-4 Feb, pp. 497-529, Lake Arrowhead, Calif.

Fairall, C., E. Bradley, J. Hare, A. Grechev, and J. Edson (2003), Bulk parameterization of air-sea fluxes: Updates and verification for the COARE algorithm, J. Clim., 4, 571-591.

Fer, I., R. Skogseth, and P. M. Haugan (2004), Mixing of the Storfjorden overflow (Svalbard Archipelago) inferred from density overturns, J. Geophys. Res., 109, C01005, doi:10.1029/2003JC001968.

Gerland, S., and R. Hall (2006), Variability of fast-ice thickness in Spitsbergen fjords, Ann. Glaciol., 44, 231-239.

Geyer, F., I. Fer, and L. H. Smedsrud (2010), Structure and forcing of the overflow at the Storfjorden sill and its connection to the Arctic coastal polynya in Storfjorden, Ocean Sci., 7, 17-49.

Goosse, H., and T. Fichefet (2001), Open-ocean convection and polynya formation in a large-scale ice-ocean model, Tellus, Ser. A, 53, 94-111.

Goszczko, I., J. Piechura, and W. Walczowski (2008), Shelf-basin exchange west of Spitsbergen - Some results from IOPAS Arctic experiments, Poster, Damocles Meeting IO PAS 2008, Sopot, Poland. 


\section{JARDON ET AL.: ICE PRODUCTION IN STORFJORDEN FROM AMSRE}

Haarpaintner, J., J. Gascard, and P. Haugan (2001), Ice production and brine formation in Storfjorden, Svalbard, J. Geophys. Res., 106, 1-13.

Hendricks, S., S. Gerland, L. H. Smedsrud, A. A. Pfaffhuber, and F. Nilsen (2011), Sea-ice thickness variability in Storfjorden, Svalbard, Ann. Glaciol., 52(57), 61-68.

Jardon, F. P., P. Bouruet-Aubertot, Y. Cuypers, F. Vivier, and A. Lourenço (2011), Internal waves and vertical mixing in the Storfjorden polynya (Svalbard), J. Geophys. Res., 116, C12040, doi:10.1029/2010JC006918.

Jardon, F. P., F. Vivier, M. Vancoppenolle, A. Lourenço, P. BouruetAubertot, and Y. Cuypers (2013), Full-depth desalination of warm sea ice, J. Geophys. Res., 118, 435-447, doi:10.1029/2012JC007962.

Kern, S. L., and S. Aliani (2011), A comparison between polynya area and associated ice production with mooring-based measurements of temperature, salinity and currents in the southwestern Ross Sea, Antarctica, Ann. Glaciol., 52(57), 409-418, doi:10.3189/172756407782871585.

Kern, S. L., G. Spreen, L. Kaleschke, S. de la Rosa, and G. Heygster (2007), Polynya Signature Simulation Method polynya area in comparison to AMSR-E $89 \mathrm{GHz}$ sea-ice concentrations in the Ross Sea and off the Adélie Coast, Antarctica, for 2002-2005: First results, Ann. Glaciol., 46(1), 409-418, doi:10.3189/172756407782871585.

Killworth, P. D. (1983), Deep convection in the World Ocean, Rev. Geophys. Space Phys., 21, 1-26.

Kusahara, K., H. Hasumi, and T. Tamura (2010), Modeling sea ice production and dense shelf water formation in a coastal polynya around East Antarctica, J. Geophys. Res., 115, C10006, doi:10.1029/2010JC006133.

Lewis, E. L., and R. G. Perkins (1983), Supercooling and energy exchange near the Arctic Ocean surface, J. Geophys. Res., 88(12), 7681-7685.

Loeng, H. (1991), Features of the physical oceanographic conditions of the Barents Sea, Polar Res., 10, 5-18.

Lynch, A. H., M. F. Glueck, W. L. Chapman, D. A. Bailey, and J. E. Walsh (1997), Satellite observation and climate system model simulation of the St. Lawrence Island polynya, Tellus, Ser. A, 49, 277-297.

Markus, T., and B. Burns (1995), A method to estimate subpixel-scale coastal polynyas with satellite passive microwave data, J. Geophys. Res., 100(C3), 4473-4487.

Martin, S., R. Drucker, and R. Kwok (2007), The areas and ice production of the western and central Ross Sea polynyas, 1992-2002, and their relation to the B-15 and C-19 iceberg events of 2000 and 2002, J. Mar. Syst., $68,201-214$.

Maus, S. (2003), Interannual variability of dense shelf water salinities in the north-western Barents Sea, Polar Res., 22(1), 59-66.

Maykut, G. A. (1986), Geophysics of Sea Ice, chap. The surface heat and mass balance, N. Untersteiner, Plenum, New York.

McPhee, M. G., R. Skogseth, F. Nilsen, and L. H. Smedsrud (2013), Creation and tidal advection of a cold salinity front in Storfjorden: 2. Supercooling induced by turbulent mixing of cold water, J. Geophys. Res., 118, 3737-3751, doi:10.1002/jgrc.20261.

Pease, C. H. (1987), The size of wind-driven coastal polynya, J. Geophys Res., 92(C7), 7049-7059.

Quadfasel, D., B. Rudels, and K. Kurz (1988), Outflow of dense water from a Svalbard Fjord into the Fram Strait, Deep Sea Res., Part A, 35, 1143-1150.

Schauer, U. (1995), The release of brine-enriched shelf water from Storfjord into the Norwegian Sea, J. Geophys. Res., 100, 16,015-16,028.

Schauer, U., B. Rudels, I. Fer, P. M. Haugan, R. Skogseth, G. Bjork, and P. Winsor (2003), Return of deep shelf/slope convection in the western Barent Sea?, paper presented at the 7th Conference on Polar Meteorol- ogy and Oceanography and joint Symposium on high-Latitude Climate Variations, Am. Meteorol. Soc., Hyannis, Mass.

Simmons, A., S. Uppala, D. Lee, and S. Kobayashi (2006), ERA-interim: New ECMWF reanalysis products from 1989 onwards, ECMWF Newsletter, 110, 25-35.

Skogseth, R., P. Haugan, and J. Haarpainter (2004), Ice and brine production in Storfjorden from four winters of satellite and in situ observations and modeling, J. Geophys. Res., 109, C10008, doi:10.1029/2004JC 002384.

Skogseth, R., P. Haugan, and M. Jakobsson (2005a), Water mass transformations in Storfjorden, Cont. Shelf Res., 25, 667-695.

Skogseth, R., I. Fer, and P. Haugan (2005b), Dense-water production and overflow from an Arctic coastal polynya in Storfjorden, AGU Nordic Seas Book Project, 25, 667-695.

Skogseth, R., A. D. Sandvik, and L. Asplin (2007), Wind and tidal forcing on the meso-scale circulation in Storfjorden, Svalbard, Cont. Shelf Res., 27, 208-227.

Skogseth, R., L. H. Smedsrud, F. Nilsen, and I. Fer (2008), Observations of hydrography and downflow of brine-enriched shelf water in the Storfjorden polynya, Svalbard, J. Geophys. Res., 113, C08049, doi:10.1029/ 2007JC004452.

Skogseth, R., F. Nilsen, and L. H. Smedsrud (2009), Supercooled water in an Arctic polynya: Observations and modeling, J. Glaciol., 55(189), 4352

Skogseth, R., M. G. McPhee, F. Nilsen, and L. H. Smedsrud (2013), Creation and tidal advection of a cold salinity front in Storfjorden: 1 . Polynya dynamics, J. Geophys. Res., 118, 3278-3291, doi:10.1002/jgrc.20231.

Smethie, W. M., H. G. Ostlund, and H. Loosli (1986), Ventilation of the deep Greenland and Norvegian Seas: evidence from Krypton-85, Tritium, Carbon-14, and Argon-39, Deep Sea Res., Part A, 33, 675-703.

Smith, S. D., R. D. Muench, and C. H. Pease (1990), Polynyas and leads: An overview of physical processes and environment, J. Geophys. Res., 95(C6), 9461-9475.

Spreen, G., L. Kaleschke, and G. Heygster (2008), Sea ice remote sensing using AMSR-E 89 Ghz channels, J. Geophys. Res., 113, C02S03, doi: 10.1029/2005JC003384.

Tamura, T., K. I. Ohshima, and S. Nihashi (2008), Mapping of sea ice production for Antarctic coastal polynyas, Geophys. Res. Lett., 35, L07606, doi:10.1029/2007GL032903.

Toudal Pedersen, L., and M. D. Coon (2004), A sea ice model for the marginal ice zone with an application to the Greenland Sea, J. Geophys. Res., 109, C03008, doi:10.1029/2003JC001827.

Vancoppenolle, M., H. Goosse, A. de Montely, T. Fichefet, B. Tremblay, and J. L. Tison (2010), Modelling brine and nutrient dynamics in Antartica sea ice: The case of dissolved silica, J. Geophys. Res., 115, C02005, doi: 10.1029/2009JC005369.

Willmes, S., T. Krumpen, S. Adams, L. Rabenstein, C. Hass, J. Hoelemann, S. Hendricks, and G. Heinemann (2010), Cross-validation of polynya monitoring methods from multisensor satellite and airborne data: A case study for the Laptev Sea, Can. J. Remote Sens., 36(Suppl. 1), S196-S210.

Willmes, S., S. Adams, D. Schoder, and G. Heinemann (2011), Spatio-temporal variability of polynya dynamics and ice production in the Laptev Sea between the winters of 1979/80 and 2007/08, Polar Res., 30, 5971, doi:10.3402/polar.v30i0.5971. 